Est Ag 42 (2007) 5-45

\title{
La integración social de los judíos romanos: extranjeros entre extranjeros
}

\author{
"Todos los caminos conducen a Roma" \\ "Mi padre era un arameo errante" (Deut 26,5)
}

El fenómeno de la inmigración es tan antiguo como la humanidad misma. Casi todos los pueblos lo han padecido en mayor o menor medida. Especial atención merece aquí el pueblo judío, ya que los avatares de la historia han hecho que Israel tuviera muy presente uno de sus credos más antiguos: ser errantes y extranjeros. Por diversas razones (económicas, guerras...), muchos judíos sintieron la necesidad o se vieron obligados a abandonar su lugar de nacimiento para irse a otros países de la cuenca mediterránea durante el siglo I de nuestra era. Las fuentes literarias, epigráficas y arqueológicas nos han dejado bastantes vestigios de la presencia judía en Egipto, Siria, Grecia, Italia..., cuyas grandes ciudades portuarias constituyeron un polo de atracción para estos judíos. Pero será la capital del imperio, Roma, centro económico, cultural y político del mundo de la época, la que atraiga hacia sí hombres de distintas culturas y religiones, haciendo que fuera el punto de confluencia por excelencia de toda la multiculturalidad imaginable para el mundo antiguo. Por eso, podemos afirmar que el viejo proverbio, "todos los caminos conducen a Roma", también era válido en la época imperial. Y los judíos no constituyeron una excepción.

Este fenómeno migratorio tuvo consecuencias de diversa índole para la capital. Aportó mano de obra y desarrollo económico, al mismo tiempo que posibilitó los intercambios culturales y religiosos. Pero en el ámbito social también trajo consigo dificultades y problemas de integración. A nivel personal, el inmigrante se enfrentaba a la cuestión de mantener su propia identidad colectiva de origen y al grado de integración en la sociedad receptora. Por integración entendemos aquí el proceso de incorporación y asimilación, en la 
conciencia y en la práctica, de las estructuras de valor y las pautas de conducta, llevadas a cabo por personas individuales en relación con determinados grupos o sectores de la sociedad relevantes para ellas, o entre distintas sociedades, o entre distintos grupos, clases o etnias de una sociedad. Gracias a la aculturación se relativiza y cuestiona la propia cultura anteriormente vivida como natural y evidente.

Los grupos extranjeros en la antigua Roma se encontraban también con el problema de la integración dentro de la sociedad romana. El término "integración" es polisémico y existiría una gran diversidad de procesos y grados de integración. El concepto aglomera múltiples dimensiones: laboral, social ${ }^{1}$ y cultural. Mayor dificultad tenían los judíos para integrarse, dado que algunas de sus tradiciones no veían con buenos ojos a los "extranjeros" y les prohibían tener cierto tipo de contactos como consecuencia de las leyes religiosas y alimenticias ${ }^{2}$. El monoteísmo exclusivista tampoco se lo ponía fácil dentro de la sociedad romana, donde lo político tenía una dimensión religiosa y viceversa. Este exclusivismo judío produjo cierta desconfianza y recelo en la convivencia con los autóctonos y con otros grupos extranjeros. Pero los judíos de la diáspora, que formaban una minoría extranjera dentro de la sociedad anfitriona, dependiendo del grado de observancia de sus costumbres de origen, harían la "vista gorda" respecto a ciertas tradiciones "xenófobas" judías y experimentarían en su propia carne el sentirse extranjero en casa de otro.

Por desgracia, el imperio romano no contaba dentro de su aparato burocrático con un centro de estudios sociológicos o una secretaría de estado de inmigración y emigración para la ciudad de Roma donde se hicieran estudios de campo, recogida de datos y análisis de los mismos. Ello nos hubiera facilitado mucho la tarea de determinar las relaciones de los inmigrantes con la sociedad anfitriona, con el resto de los extranjeros, así como los mecanismos a disposición de los judíos para acoger e integrar a sus connacionales recién llegados a Roma.

Este artículo no pretende, lógicamente, hacer un estudio sociológico de la sociedad romana, ni analizar todos los parámetros y variables que confluyen en el fenómeno de la inmigración. Nuestro objetivo es mucho más reducido. Conocida la estrecha vinculación de los seguidores de Jesús con su matriz cultural, religiosa y étnica judía en Roma, es necesario mostrar la compo-

1 Se refiere al trato entre extranjeros y autóctonos, que significaría una intensificación de los lazos de vecindad, de camaradería y amistad, de modo que compartieran actividades de tiempo libre y llegaran a formar familias mixtas. La integración cultural implica la aceptación de las normas básicas que rigen la convivencia.

2 Cf. Reinhard Feldmeier - Ulrich Heckel (ed.), Die Heiden. Juden, Christen und das Problem des Fremden (WUNT 70), J.C.B. Morh (Paul Siebeck), Tübingen 1994. 
sición de la comunidad judía en la capital del imperio para determinar posteriormente el comportamiento sociocultural y el sentido de pertenencia de los inmigrantes judíos. Los seguidores de Jesús en Roma serán a su vez inmigrantes en esta ciudad cosmopolita. Ello nos lleva a considerar la situación de los extranjeros en la capital del imperio y los tipos de interacciones que los judíos tienen con sus conciudadanos, especialmente a nivel religioso. El análisis de la interacción de los judíos con otros grupos dentro de la ciudad, ayudará a comprender la composición de las comunidades domésticas cristianas romanas. Es en ese momento histórico cuando se está perfilando la identidad de esas comunidades, tanto ad intra como ad extra. Ése sería el contexto histórico y social de la carta de Pablo a los Romanos, y el apóstol quiere influir en esa configuración. No obstante, éste será tema de un próximo estudio.

\section{Roma, ciudad multicultural}

A finales de la República y a principios del Principado, la población de Roma aumentó considerablemente debido, en gran parte, a la afluencia de forasteros de los lugares conquistados. Gran parte de esta población estaba formada por esclavos y otros que lo habían sido. Entre los grupos de extranjeros que había en Roma, los judíos llamaban la atención por su exclusivismo social y por sus peculiares creencias y prácticas religiosas. A mediados del siglo I d.C., el elemento extranjero constituía la mayor parte de la plebe urbana, de la servidumbre y una gran proporción de los peregrini. Hacia el año 14 d.C., Roma tenía al menos 750.000 habitantes, lo que significaba más de una décima parte de la población total de Italia ${ }^{3}$. Fue mayor que cualquier otra ciudad occidental hasta el siglo XIX. Roma era una ciudad cosmopolita ${ }^{4}$, una peque-

${ }^{3}$ Dato tomado de Bruce W. Frier, Demography, en: Alan K. Bowman - Peter GARNSEY - Dominic RATHBone, The Cambridge Ancient History. Second Edition. Volume XI: The High Empire, A.D. 70-192, Cambridge University Press, Cambridge 2000,787-816, aquí 813. JÉRÔME CARCOPINO, La vida cotidiana en Roma en el apogeo del Imperio, Ediciones Temas de Hoy, Madrid 1989, 39, estima que la población de Roma bajo el reinado de Agusto era "un número cercano al millón, si no superior". Se trataba de la ciudad tentacular y colosal cuya grandeza maravillaba a extranjeros y provincianos. PHILIP F. ESLER, Conflicto e identidad en la carta a los Romanos. El contexto social de la carta de Pablo, Verbo Divino, Estella 2006, 127, propone una población aproximada entre 800.000 y 900.000 habitantes a medidados del siglo I. d.C.

${ }^{4}$ Cf. La introducción "Cosmopolis: Rome as World City" en Catharine Edwars Greg Wolf (eds.), Rome the Cosmopolis, Cambridge University Press, Cambridge 2003,120; Diane FaVRo, Making Rome a World City, en: KARL GalinSKY (ed.), The Cambridge Companion to the Age of Augustus, Cambridge University Press, Cambridge 2005, 234-263; John E. Stambaugh, The Ancient Roman City, The John Hopkins University Press, Baltimore, Maryland 1988, 94-95. 
ña oikoumene, donde se encontraban representados la mayor parte de los pueblos conquistados. Los extranjeros ${ }^{5}$ pululaban en sus calles y enriquecían la textura de la vida urbana. Se ha intentado estimar la proporción de los extranjeros en la población de la ciudad. Pero, además de la ausencia de estadísticas, es difícil definir cuándo un individuo dejaba de ser un "extranjero" y se convertía en "romano", y cómo determinar si un ciudadano extranjero ya había recibido la ciudadanía romana antes de llegar a Roma. Sin lugar a dudas, los extranjeros llegaron a Roma de todos los rincones del imperio, trayendo consigo su cultura, su lenguaje, sus costumbres y su religión. Ya en el 242 a.C., Roma sintió la necesidad de instituir el cargo de praetor peregrinus con el objetivo de regular en la ciudad las relaciones jurídicas entre los romanos y los extranjeros de la ciudad, o entre los mismos extranjeros. En Roma existían importantes minorías: sirios, egipcios ${ }^{6}$, judíos... Todos ellos eran extranjeros a los ojos de los romanos. Cuanto más se convirtió Roma en una ciudad universal, más aparecieron resentimientos y recelos de los romanos autóctonos frente al elemento extranjero de la población. Esto se constata en expulsiones de extranjeros y en un texto de Juvenal (Sátira III), quien se lamenta de que Roma se haya convertido en un bazar oriental. La visión que tenían los romanos refleja los procesos de estereotipación de los exogrupos étnicos. La aversión romana hacia el extranjero se correspondería a la antipatía que los pueblos dominados sentirían hacia los romanos y sus evidentes defectos, como el modo en que ejercían el poder para extraer toda la riqueza de los pueblos sometidos y su brutalidad en el extranjero.

David Noy ${ }^{7}$, estudiando los testimonios epigráficos y literarios, ha establecido los grupos étnicos existentes en la capital, el tipo de trabajos que realizaban y cómo se integraban en la sociedad romana. En la primera sección de su libro intenta definir el status social y legal del extranjero en Roma. También discute cuestiones demográficas examinando la proporción de extranje-

5 JUTTA DESKEN-WEILAND, Fremde in der Bevölkerung des kaiserzeitlichen Rom, en: $R Q 98$ (2003) 18-34; EMILIA NDIAYE, L'etranger 'barbare' a Rome: essai d'analyse semique, en: $A C 74$ (2005) 119-135. Para la actitud de los romanos hacia los extranjeros cf. J.P.V.D. BALSDON, Romans and aliens, London 1979, y el capítulo tercero "Attitudes to foreigners" de David Noy, Foreigners at Rome. Citizens and Strangers, Gerald Duckworth \& Co. Ltd., London 2000, 31-50.

6 Cf. DAVID NoY, Being an Egyptian in Rome. Strategies of Identitiy Formation, en: JÜRGEN ZANGENBERG - MICHAEL LABAHN (eds.), Christians as a religious minority in a multicultural city. Modes of interaction and identity formation in early imperial Rome. Studies on the basis of a seminar at the Second Conference of the European Association for Biblical Studies (EABS) from July 8-12, in Rome (Journal of the Study of the New Testament. Supplement series 243), T \& T Clark, Edinburgh 2004, 47-54.

7 David NoY, Foreigners at Rome. Citizens and Strangers, Gerald Duckworth \& Co. Ltd., London 2000. 
ros que componían la población de la ciudad, si esos extranjeros eran ciudadanos y la actitud hacia los extranjeros. Interesante también es la tercera sección de su libro donde examina la experiencia étnica en la ciudad y hasta qué grado mantuvieron los extranjeros sus identidades étnicas. El capítulo octavo expone los tipos de grupos extranjeros residentes en la capital, lo que nos ayuda a entender la composición de la población extranjera en Roma. Este historiador define el concepto de "extranjero" como "quien ha nacido fuera de Italia y ha emigrado a Roma, pero continúa teniendo una 'casa' (en su propio pensamiento o en el de otras personas) en algún otro lugar" 8 . Ser extranjero tenía su implicación legal. Peregrinus es un extranjero o forastero o un ciudadano de otro estado que no fuera Roma, y en términos de jerarquía social ocupaba una posición entre el esclavo y el ciudadano. Pero no todos los extranjeros eran iguales ante la ley9.

Veamos brevemente la división jurídica existente entre los habitantes de Roma. Gayo, escribiendo su libro de texto sobre la ley romana en el siglo II d.C., emitió una clasificación sustancial de la raza humana ${ }^{10}$ en lo que era relevante para el derecho romano: "La primera distinción en la ley de las personas es ésta, que todos los hombres son libres o esclavos. Después, los hombres libres son o bien ingenui (nacidos libres) o libertini (libertos). Los ingenui son quienes han nacido libres, y nacen libres los dados a luz por una madre libre y nunca han sido esclavos en derecho. Los libertini son quienes han sido manumisos de la esclavitud legalmente. Dentro de los hombres libres existen tres clases: los ciudadanos romanos, los latinos y la categoría de dediticii ${ }^{11}$ " (Inst. I.3.9-12). Con respecto a la ciudadanía, Gayo clasifica a los habitantes de Roma en ciudadanos, latinos y peregrinos.

Ciudadano romano es toda persona libre que tiene el derecho de ciudadanía (civitas, ius civitatis) y forma parte del pueblo romano con todos los derechos, obligaciones y prerrogativas. Los ciudadanos participaban de todas las

8 Idem, xi.

${ }^{9}$ Un peregrino a los ojos de la ley romana, no podía demandar derechos políticos, estaba excluido del servicio militar y no podría hacer un testamento, cf. ADOLF BERGER, Encyclopedic Dictionary of Roman Law, Philadephia 1953, s.v. peregrinus; JANE GARDNER, Being a Roman Citizen, London - New York 1993, 186-188; A.N. SHERWIN WHITE, The Roman Citizenship, Oxford 19732 , 268-269.

10 Cicerón divide el mundo en tres grandes grupos, "griegos, romanos y bárbaros", lo cual tiene su correspondiente expresión geográfica (Cicerón, fin 2,49: Graecia, Italia, Barbaria). El NT refleja asimismo las diferencias entre pueblos, pues según Col 3,11 se diferencian judíos y griegos, circuncisos e incircuncisos, bárbaros y escitas, esclavos y libres. Aunque las diferencias geográficas y étnicas de los pueblos desaparecen en la unidad de la fe $(\mathrm{Gal} \mathrm{3,28)}$.

11 Pueblos que se han rendido sin condiciones ante Roma. 
instituciones de derecho civil romano público y privado ${ }^{12}$. Entre los ciudadanos había primitivamente una distinción: unos formaban el orden predominante (patricii), eran ciudadanos de pleno derecho; otros eran considerados de un rango inferior (plebei, plebs). Una pequeña porción de los habitantes del imperio poseía la ciudadanía romana. Se estima que en el año 28 a.C., cinco o seis millones eran ciudadanos romanos, de los que cuatro millones vivirían en Italia ${ }^{13}$. Se caracterizaban, entre otras cosas, por el tria nomina. El emperador Claudio (41-54 d.C.) consideró ilegal para los extranjeros adoptar los nombres de familias romanas y ejecutó a otros que habían usurpado los derechos de los ciudadanos romanos ${ }^{14}$. La concesión de la ciudadanía romana (y del derecho latino ius Latii) a los no romanos se otorgó en un principio a nivel personal, con el objetivo de vincular a los líderes locales con el estado central ${ }^{15}$, o como concesión por la lealtad mostrada.

Los latinos y peregrinos gozaban de algunos derechos, pero con muchas limitaciones. En el fondo, los latinos eran peregrinos pero tratados con ciertas ventajas comprendidas en el derecho de ciudadanía romana ${ }^{16}$. Los libertinos, al adquirir la libertad por manumisión, podían quedar adscritos a uno de los órdenes de personas libres: o bien adquirían la libertad mayor y quedaban hechos ciudadanos romanos; o bien la menor y pasaban ser a latinos, según la ley Junia Norbana; o bien la inferior y, en virtud de la ley Sendia, se convertían en dediticios. Los manumitidos, aunque consiguieran la ciudadanía, seguían distinguiéndose de los ingenuos por dos conceptos: 1) En el aspecto jurídico tenían un puesto inferior en la sociedad; 2) en el aspecto familiar quedaban ligados con ciertas obligaciones hacia sus patronos. El número de libertos era elevado en Roma. A ellos hay que añadir la masa de hombres libres que in-

12 Los derechos del ciudadano en el orden privado son: el connubium (facultad de contraer matrimonio de derecho civil), el comercium (derecho de recibir y transmitir la propiedad). En el derecho público, el ius suffragii (derecho a votar en los comicios), ius honorum (derecho a ejercer las funciones públicas y religiosas), provocatio ad populum (derecho a no sufrir una pena capital pronunciada por algún magistrado). Entre los ciudadanos se distinguen tres estamentos: los senadores, los caballeros y los de tercer estado, cf. JosÉ GuILlÉN, Urbs Roma. Vida y costumbres de los romanos. IV: Constitución y desarrollo de la sociedad (PD 27), Ediciones Sígueme, Salamanca 2000,131-195.

13 Cf. SusAn Treggiari, Social Status and Social Legislation, en: The Cambridge Ancient Historiy. X: The Augustan Empire, 43 B.C.-A.D. 69, Cambridge University Press, Cambridge $2004^{3}, 873-904$, donde analiza ampliamente las distinciones sociales (órdenes, riqueza, nacimiento...), así como la cuestión de la manumisión (893-897). Sobre la manumisión cf. José GuILlÉN, Urbs 311-320.

14 Suetonio, Claud 25,3: "Peregrinae condicionis homines vetuit usurpare Romana nomina dumtaxat gentilicia. Civitatem Romanam usurpantes in campo Esquilino securi percussit".

15 Cf. Aelio Arístides, Or. 26.64.

16 Cf. JosÉ GuilléN, Urbs 246ss. 
migraban a la ciudad continuamente de todas las provincias. Luciano dice que Roma es una ciudad no poblada por sus propios ciudadanos, sino por la hez de todo el mundo. Algunos romanos de comienzos del siglo II d.C. se quejaban de que Roma se había constituido en una ciudad griega y no se podía vivir en ella ${ }^{17}$. Lo cierto es que los ciudadanos romanos disminuían y el conglomerado de libertos extranjeros iba aumentando en la ciudad.

Los pueblos conquistados no se convertían en ciudadanos automáticamente, incluso aunque su territorio se convirtiera en provincia. Cicerón y otros autores se refieren a estas gentes como provinciales (provinciales), literalmente esos que pertenecen a la provincia, pero este uso incluía tanto a ciudadanos y no ciudadanos, sin ninguna distinción respecto a su status legal18. Otro término ampliamente usado fue el concepto de extranjero (peregri$n u s)^{19}$. Un peregrino era originalmente cualquier persona que no era de Roma o de una colonia romana. Los provinciales no ciudadanos (generalmente provinciales y legalmente peregrini) dejaban de ser bárbaros en virtud de haber adquirido la residencia legal dentro del imperio. Permanecían en esta categoría hasta que se convertían en ciudadanos o residentes de una ciudad con privilegios legalmente reconocidos, con el status latino, lo que le situaba legalmente entre un ciudadano romano y un peregrinus. La residencia se convirtió en una segunda categoría frecuentemente usada para identificar a las personas.

Los romanos denominaban a los pueblos extranjeros nationes o gentes exterae. Desde el siglo II a.C. se utilizaron los términos exterus y barbarus como sinónimos, aunque el significado de bárbaro era múltiple ${ }^{20}$. Podía designar a quien hablaba otra lengua, al extranjero, a los enemigos de la patria, a los iletrados, o a los miembros de un pueblo forastero y extranjero ${ }^{21}$. Exis-

17 Juvenal, Sátiras 3,21s.

18 Thomas S. Burns, Rome and the Barbarians 100 B.C.-A.D. 400, Johns Hopkins University Press, Baltimore, Maryland 2003, 32-35.

19 Cf. GotTfried Schiemann, Peregrinus, en: Der Neue Pauly. Enzyklopädie der Antike Bd. 9, Verlag J.B. Metzler, Stuttgart - Weimar 2000, 540s: "Peregrinus ist der wichtigste t.t. des röm. Rechts für den Fremden, der nicht dem Rechtsverband der röm. Bürger angehört, ohne doch ein Feind oder überhaupt rechtlos zu sein".

20 Cf. ThlL 2, 1729-44; W. SPEYER, Barbar I, RAC Suppl. Bd. I, 1992, 811-895; R.M. SCHNEIDER, Barbar II (ikonographisch), RAC Suppl. Bd. I, 1992, 895-962; VOLKER LOSEMANN, Barbaren, en: Der Neue Pauly. Enzyklopädie der Antike Bd. 2, Verlag J.B. Metzler, Stuttgart - Weimar 1997, 439-443. El carácter negativo de este concepto se constata en los atributos que solían aplicarse a la persona bárbara: feritas, immanitas, inhumanitas, impietas, ferocia, superbia, impotentia, furor, discordia, vanitas, perfidia, imprudentia.

21 BRENT D. SHAw, Rebels and Outsiders, en: The Cambridge Ancient History. XI: The High Empire A.D. 70-192, Cambridge University Press, Cambridge 2000, 374: "The 'barba- 
tía una imagen negativa y unidimensional de los forasteros. El bárbaro era considerado como la negación de la sociedad civilizada. El aspecto negativo de la imagen romana del extranjero estaba anclada en la inferioridad probada de su forma de vida. No obstante, la sociedad romana asimiló paulatinamente a los bárbaros. De esta forma, la sociedad cambió, pero como todos los cambios sociales, necesitó varias generaciones. Si es verdad que normalmente se denominaba bárbaros a las gentes que no estaban dentro del imperio, también existían los "bárbaros internos"22, como eran los judíos, quienes corrían la misma suerte que los externos. Es más, los griegos y romanos utilizaron el concepto de bárbaro como insulto contra los judíos 23 .

Por otra parte, en Roma no se reconocían los derechos nacionales extranjeros. Por tanto, el extranjero era frecuentemente casi un esclavo en Roma. ¿Cuantos esclavos habría en la capital? No es fácil precisarlo, pero podemos sospechar su elevado número por las noticias que Ateneo ${ }^{24}$ nos da. Gran parte de los judíos que llegaron a la ciudad en tiempo de Pompeyo, lo hicieron en contra de su voluntad. No hay ninguna razón para pensar que los esclavos judíos obtuvieran la libertad rápidamente, pero se beneficiarían, como el resto de los esclavos de otras nacionalidades, de la concesión de la libertad y algunos obtendrían incluso la ciudadanía romana al realizarse esa manumisión de forma legal ${ }^{25}$. Cuando Filón se refiere a tales judíos como ciudadanos romanos (Legatio 155, 157), puede que generalizara, pero su referencia a la recogida de la distribución del grano (ídem 158), confirma que algunos judíos adquirieron la ciudadanía.

Una de las formas más usuales para la identificación de los individuos en el mundo romano fue la pertenencia a un 'pueblo' o a una 'etnia', frecuente-

rian' is a type of totalized stranger that characteristically appears in the culture of a host society during the period of its territorial or commercial expansion". La imagen de los bárbaros persistió, aunque fuera de forma latente, en el trasfondo de las ideas sobre los extranjeros y ayudó a determinar una clasificación más general de los extranjeros en la sociedad romana.

22 E. FASCHER, Fremder, en: RAC VIII (1972) 324: "Es gibt F[remder] im Innern, die Provinzialen, besiegte Völker, die an ihren Gesetzen, ihrer Sprache und Religion festhalten dürfen und bisweilen ein gewisses $\mathrm{Maß}$ an administrativer Unabhängigkeit bewahren... Doch gibt es auch F. außerhalb der Reichsgrenzen (diejenigen, die Tacitus 'die Barbaren' nennt)".

23 Cicerón, Flacc 28,67: la religión judía es una superstitio barbara; Juvenal, Sátiras VI 157s; Sext. Emp. adv.math 1,314; hypot.3,203; Filón, Legatio 215; PsClem.Rom, hom. 4,13. Apolonio Molón en Josefo, c.Apion 2,148 consideró que los judíos eran el pueblo bárbaro más inepto. Los paganos usaron la palabra bárbaro fundamentalmente en un sentido étnico, cultural y moral.

24 Ateneo, Banquete de los eruditos I 20 B, habla de Roma como "población o compendio del mundo" con una lengua local llena de extranjerismos (III $121 \mathrm{~F}$ ).

25 Sólo la manumisión formal concedía la ciudadanía, mientras que la concesión informal de la libertad otorgaba únicamente el status de peregrinus. 
mente ligado a un lenguaje o dialecto común. Es sumamente complicado determinar el hecho de la etnicidad ${ }^{26}$, pero éste era uno de los identificadores más poderosos dentro de las sociedades del imperio. La consideración de la etnicidad y el valor moral que les atribuían eran particularmente fuertes porque el conocimiento acerca de 'otros pueblos' estaba basado fundamentalmente en la sabiduría popular (estereotipos): ¿por qué los sirios, judíos e idumeos eran altamente intrigantes? (cf. Ptol. Apotel. II 3,65-66 = Stern ${ }^{27} 1980$, $\mathrm{n}^{\circ}$ 336a). Éstos constituían los 'bárbaros internos', que como los judíos o egipcios, por su distanciamiento del gobierno y de la cultura común de la oikoumene, fueron insultados como 'gentes nacidas para esclavitud'28.

\section{Presencia y organización de los judíos en Roma}

A mediados del siglo I de nuestra era, la comunidad judía de Roma estaba ya bien establecida y con una historia de más de cien años. Existe un testimonio controvertido (Valerio Máximo, 1,3,3) que testimonia la expulsión de cultos orientales por sus actividades proselitistas en el año 139 a.C., medida que pudo afectar a los judíos. Pero el valor histórico de la fuente y la existencia de una comunidad judía en Roma en esa época es, sin embargo, dudosa ${ }^{29}$. Las fuentes son más fiables a partir del 59 a.C. (Cicerón, Flacco 66), y especialmente para el reinado del emperador Augusto (Filón, Josefo, Suetonio, así como indicaciones de Horacio y Ovidio ${ }^{30}$ ). Josefo, Tácito y Suetonio mencionan en tiempos de Tiberio (19 d.C.) una deportación de los judíos de Roma (según Tácito, de Italia): 4000 judíos fueron enviados a Cerdeña a luchar contra los bandidos ${ }^{31}$. Al menos otra expulsión tuvo lugar en tiempos del emperador Claudio (49 d.C.) $)^{32}$.

26 PhILIP F. EsLer, Conflicto 67, constata la dificultad de definir el concepto de etnicidad: "Un 'grupo étnico' puede describirse de forma provisional... como aquél cuyos miembros creen que comparten una historia e incluso una ascendencia común, a menudo en relación con su ocupación actual o pasada de un determinado territorio y con la práctica de unas costumbres semejantes".

27 M. STERN, Greek and Latin Authors on Jews and Judaism, Israel Academy of sciences and Humanities, Jerusalem 1980.

28 Cicerón, Flac 28,69; Prov. Cons 5,10-12; Tácito, Historia V 7.

29 Para una panorámica histórica de los judíos en Roma D. Álvarez CineIRA, Die Religionspolitik 188-214.

30 B. WANDY, Jewish Religion in Pagan Literature during the Late Republic and Early Empire, en: ANRW II 19.1 (1979) 596-613.

31 Josefo, AJ 18,80; Tácito, Ann 2,85; Suetonio, Tib 36. Estas fuentes no concuerdan en muchos detalles.

32 Dion Casio, LX 6,6 menciona una expulsión en el 41 d.C.; Suetonio, Claud 25,4; Hechos 18,2 . 
La importancia numérica de la colonia judía en Roma viene sugerida por Flavio Josefo ( $B J$ II 80: unos ocho mil hombres) y Filón de Alejandría, en su tratado Embajada a Cayo. Esta obra ofrece un panorama general de la situación de los hebreos en la capital del imperio. La población exacta de judíos en Roma a mediados del siglo I d.C. es difícil de estimar y los estudiosos proponen cifras que oscilan entre 25.000 y $60.000^{33}$. Por eso podemos afirmar con algún autor que a mediados del siglo I d.C., con la estimación de casi un millón de habitantes en Roma, la comunidad judía constituía entre el 3 y el 5 \% de su población total. Es decir, era suficientemente numerosa como para pasar desapercibida, pero no tan numerosa como para convertirse en una entidad independiente dentro de la ciudad ${ }^{34}$. Este incremento de la población judía dentro de la ciudad de Roma no se puede explicar como el éxito de los esfuerzos proselitistas judíos, sino más bien fruto de la inmigración. De las inscripciones conservadas, se concluye que las comunidades judías en Roma hablaban griego, dato muy importante para el contexto de la carta de Pablo ${ }^{35}$. Por eso, es de suponer que muchos de ellos provenían de la región de Siria ${ }^{36}$. La mayor parte de los judíos -antiguos esclavos, libertos, mercaderes, aventureros y, en general, inmigrantes- vivirían en Roma como residentes extranjeros, pero con el tiempo algunos obtuvieron la ciudadanía romana.

La población judía en Roma parece haberse concentrado en ciertos barrios de la ciudad, como se desprende de la presentación de Filón sobre los ju-

33 Véanse las diferentes hipótesis en H. Solin, Juden und Syrer im westlichen Teil der römischen Welt. Eine ethnisch-demographische Studie mit besonderer Berücksichtigung der sprachlichen Zustände, en: $A N R W$ II 29.2 (1983) 698-700. R. Penna sugiere que eran unos 20.000 judíos durante el reinado de Nerón, R. PENNA, Les Juifs à Rome au temps de l'apôtre Paul, en: NTS 28 (1982) 328.341 n. 53.

34 STEPHEN SPENCE, The Parting of the Ways. The Roman Church as a Case Study (Interdisciplinary Studies in Ancient Culture and Religion 5), Peeters, Leuven - Dudley, MA 2004,19 . Siempre es difícil fijar y valorar estas cifras, por eso no es raro encontrar quien piensa que en tiempos de Claudio vivían en Roma unos 40-50 mil judíos de una población de 400.000 habitantes, lo que supone que la minoría judía constituía más del $10 \%$ de la población de Roma, así lo piensan BEN WITHERINGTON III - DARLENE HyATT, Paul's Letter to the Romans. A Socio-Rhetorical Commentary, William B. Eerdmans, Grand Rapids, Michigan - Cambridge, U.K., 2004, 12. Si tenemos en consideración que existían otras grandes minorías en la ciudad, habría que concluir que el sustrato demográfico romano era otra minoría. Es decir, Roma era una ciudad compuesta eminentemente de extranjeros.

35 Las inscripciones son en su mayor parte en griego. Las inscripciones en latín son más raras y más tardías. El hebreo es menos frecuente y suelen ser fórmulas religiosas, cf. H.J. LEON, The language of the greek inscriptions of the Jewish Catacombs of Rome, en: TAPA 58 (1927) 210-233; Idem, The Jews of Ancient Rome, The Jewish Publication Society of America, Philadelphia 1960, 75-92; H. Solin, "Juden" 701-710. D. NoY, Jewish Inscriptions of Western Europe. 2. The City of Rome, Cambridge 1995.

36 Sobre el origen y la situación social de los judíos en Roma cf. H.J. LEON, Jews 233239; H. Solin, "Juden” 713-320. 
díos romanos (Leg 155-158) y de algunos poetas romanos. Los judíos se ubicaron principalmente en los suburbios de Roma, especialmente en el Trastévere, cuyos barrios, estrechos y populares, sirvieron de "barrio para extranjeros" de la antigua Roma. Según fue creciendo la comunidad judía y las posibilidades económicas, algunos judíos se mudaron hacia otras partes de la ciudad, especialmente al barrio Suburra en el este, pobre y sucio, y al barrio de Campo de Marte ${ }^{37}$, algo más respetable. Pero la comunidad judía nunca destacó por su riqueza, sino más bien por todo lo contrario. Según Juvenal son conocidos públicamente los mendigos judíos (Sátiras III 13-16), y sabemos por Filón que parte de la población judía de Roma dependía del suministro de trigo organizado por las autoridades públicas ( Leg 155). En este aspecto no se diferenciaban de la mayoría de los extranjeros en Roma.

La frecuente designación de las instituciones y funciones en las inscripciones romanas permite reconocer en general la organización de los judíos en la capital. De forma diferente a Alejandría, las comunidades estaban organizadas de forma independiente. La investigación reciente ha puesto de manifiesto que existían considerables variaciones en su estructura y en los títulos de sus funcionarios, muchos de los cuales reflejaban la titularidad de otras organizaciones grecorromanas. Algunos títulos revelan diversas funciones y puestos de honor ${ }^{38}$, concedidos por proporcionar recursos financieros para las

37 P. LAMPE, Die stadtrömischen Christen in den ersten beiden Jahrhunderten. Untersuchungen zur Sozialgeschichte (WUNT II 18), 2. Aufl., J.C.B. Mohr (Paul Siebeck), Tübingen 1989, 28: "Ob also schon im 1. Jh. n.Chr. dort [en el Campo de Marte y en Suburra] Judensiedlungen bestanden, aus denen sich christliche Gemeindekreise hätten entwickeln können, muss hingestellt bleiben. Sicher im 1. Jh. n.Chr. lebten Juden in Trastevere (wie LegGai 155 bestätigt), zwischen Porta Collina y Porta Esquillina sowie vor der Porta Capena".

38 A la cabeza de la comunidad se encuentra la asamblea de los ancianos, la gerusia, con el gerusiarchonte como representante de la comunidad. Mientras que el título presbyteros prácticamente no aparece, se encuentra frecuentemente el de archonten. Para una descripción detallada de la organización y posición de las comunidades judías en Roma, veáse $J$.B. FREY, Les communautés juives à Rome aux premier temps de l'Église, en: $R S R$ 21 (1931) 129-168. Según este autor, encontramos aquí a los miembros de un gremio: "La organización de las comunidades romanas copiaba la organización de las ciudaes greco-romanas y de las asociaciones" (p. 158). Cf. también H.J. LEON, Jews 167-194; W. WIEFEL, Die jüdische Gemeinschaft im antiken Rom und die Anfänge des römischen Christentums. Bemerkungen zu Anlaß und Zweck des Römerbrieg, en: Jud 26 (1970) 73-75; H. SoLIN, "Juden" 696ss. G. LA PiAna, Foreign Groups in Rome during the first Centuries of the Empire, en: HThR 20 (1927) 356.363.382, defiende otra opinión. MARGARET H. WILLIAMS, The structure of Roman Jewry re-considered. Were the synagogues of ancient Rome entirely homogeneous, en: ZPE 104 (1994) 129-141, investiga las estructuras internas de las sinagogas de la ciudad de Roma y llega a la conclusión: "the synagogues of Rome, founded at different times and by Jews from different parts of the Jewish world, were not quite as homogeneous as is generally thought" (p. 130). 
diversas actividades sociales y religiosas. La población judía romana se caracterizaba por la heterogeneidad de sus miembros ${ }^{39}$, la multiplicidad de las comunidades judías dentro de la ciudad ${ }^{40}$, la organización democrática y la ausencia de una autoridad central judía ${ }^{41}$. Este sistema facilitó a los seguidores de Jesús el acceso a las sinagogas y ganar adeptos en ellas para su causa. Cada sinagoga era más o menos independiente ${ }^{42}$, aunque mantenían un cierto contacto entre sí. Al mismo tiempo, se caracterizaban por mantener una estrecha relación política e intelectual con Jerusalén y Palestina ${ }^{43}$. Por desgracia, no se ha conservado ningún resto arqueológico de esas sinagogas, es más, muchos autores piensan que el término sinagoga se refiere a la congregación de los judíos, no al lugar donde se reunían ${ }^{44}$. No es imposible que a mediados del siglo

39 G. LA PIANA, "Foreign" 363, describe la composición de la comunidad judía romana con las siguientes palabras: "The Roman Jewry was by no means a homogeneous body; it included inmigrants from various cities of the diaspora as well as a large number of Jews from Palestina...".

40 De las once o trece sinagogas de la antigua Roma, de las cuales nos han llegado sus nombres, se supone que en el siglo I d.C. ya existían al menos tres o cuatro: la sinagoga de los augustenses, de los agripenses, de los hebreos y de los vernáculos, cf. H.J. LEON, The Jews 149ss; J. GOODNICK WESTENHOLZ, The Jewish Presence in Ancient Rome, Bible Lands Museum Jerusalem 1995, 23-27. Peter Richardson, Augustan-Era Synagogues in Rome, en: KARL P. DONFRIED - PETER RICHARDSON (ed.), Judaism and Christianity in First-Century Rome, B. Eerdmans, Grand Rapids, Michigan - Cambridge 1998, 17-29, considera que la comunidad de Roma era suficientemente fuerte y numerosa como para poder contar probablemente con cinco sinagogas para esta época, dedicadas a Augusto, a su yerno Marco Agrippa, a Herodes, a un tribuno de Siria y la sinagoga original de los hebreos. "There may have been more, though most of the other eight synagogues probably developed in the second and third centuries C.E." (29). Sobre los nombres de las sinagogas, cf. H.J. LEON, Jews 140-166, y G. LA PIANA, "Groups" 351359. P. LAMPE, Christen $367 \mathrm{~s}$, menciona catorce sinagogas.

41 P. LAMPE, Christen 368, considera las sinagogas romanas como "selbständig organisierte Einzelgemeinden mit je eigenem Versammlungsort, einer Gerusie und eigenen Gemeindebeamten. Untereinander waren diese Gemeinden nur locker assoziiert". También H.W. TAJRA, The Trial of Paul (WUNT II 35), Tübingen 1989, 183; según este estudioso, la infraestructura de las comunidades judías de Roma no estaba agrupada en un única comunidad, pero al mismo tiempo subraya: "there was still a fundamental unity among the several Jewish communities there: strong unifying bonds of race, of national aspirations as well as of religious law and practice". Pocos investigadores defienden otra opinión diferente, excepto. G. LA PIANA, "Groups" 361s.: "The evidence of the inscriptions leaves no doubt of the existence in imperial times of officers for the whole Jewish community. On general grounds a central organ of government... can not have been lacking in Rome".

42 Margaret H. Williams, "Structure" 129-141.

43 Así creen también R.E. Brown - J.P. MEIER, Antioch and Rome. New Testament Cradles of Catholic Christianity, New York - Ramsey 1983, 96; H.J. LEON, Jews 35-38; S. LIEBERMANN, Response to the Introduction by Professor AleXANDER MARX, en: J. GOLDIN (ed.), The Jewish Expression, New Haven, Yale 1976, 129-131; G. LA PIANA, "Groups" 345, menciona las tres características fundamentales del judaísmo romano: "Their concentration in special districts, their religious associations and their relation with the land of origin".

44 Ello se ha podido deber a los avatares del destino; MARY BEARD - JOHN NORHT SIMON PRICE, Religions of Rome. Volumen I: A History, Cambridge University Press, Cam- 
I d.C., algunas congregaciones judías se reunieran en lo que una vez habían sido o podrían seguir siendo espacios domésticos, pero los judíos probablemente ya se encontraban en una fase en la que poseían construcciones utilizadas exclusivamente para las funciones de la comunidad. Esta afirmación viene corroborada por datos epigráficos y literarios irrefutables (cf. Filón, Legat 156s, y los restos de una sinagoga de mediados del siglo I d.C. cerca de Ostia; Juvenal, Sátiras III 296) ${ }^{45}$. En el siglo I y principios del siglo II d.C., las congregaciones se referían a sí mismas como sinagogas y a los edificios donde se reunían los llamaban proseuchai. Éstas estaban abiertas incluso a los no judíos. Dicha situación implica que el contexto social y arquitectónico de las asambleas judías era muy diferente al de las comunidades de los discípulos de Cristo en Roma, que se reunían en algunas casas de sus miembros. Este aspecto tiene implicaciones importantes para las respectivas identidades de los judeos y los discípulos de Cristo, a los que Pablo se dirige.

La sinagoga sirvió como centro de la vida comunitaria judía, tanto en sus dimensiones religiosas como sociales. Los judíos en Roma pertenecían a la comunidad judía local. Se consideraban a sí mismos como una entidad distinta y semi-autónoma, y como tal fue vista por los no judíos. En este ámbito, como en otros muchos, tampoco se diferenciaban excesivamente con respecto al resto de las muchas comunidades extranjeras que habían hecho de Roma su casa.

Las fuentes conservadas no permiten determinar las prácticas religiosas de la comunidad judía de Roma. Únicamente sabemos que contribuían a la manutención del templo tal y como estaba prescrito y participaban en las peregrinaciones a Jerusalén. Filón nos informa que los judíos romanos tenían sus casas de oración y se reunían en ellas, especialmente los sábados sagrados cuando recibían instrucción de su filosofía ancestral. El emperador Augusto conocía que los judíos realizaban las colectas de sus primicias y las enviaban a Jerusalén por medio de personas que ofrecían sacrificios (Legat 156). No existen evidencias de que las divisiones religiosas de Palestina estuvieran presentes en la diáspora. Pero tampoco se puede concluir que el judaísmo de la diáspora observase un judaísmo normativo monolítico. A pesar de las variaciones locales en la práctica del judaísmo, la práctica de lo fundamental del judaísmo hacía que las diversas variedades pudieran ser incluidas dentro del judaísmo común 46 .

bridge 1998, 267: "But it may also be that most of these synagogues were simple meeting places in houses, leaving no permanent marks of their religious function"; PHILIP F. ESLER, Conflicto 133.

45 Philip F. Esler, Conflicto 136ss.

46 Stephen Spence, The Parting 28. 


\section{La identidad étnica judía}

Las designaciones étnicas derivaban casi siempre del territorio que los grupos en cuestión ocupaban o que alguna vez habían ocupado. La designación territorial de un grupo étnico no sólo indicaba el lugar de origen ${ }^{47}$, sino que también expresaba la posibilidad de que este grupo pudiera tener un determinado carácter debido al ambiente de la tierra. Aunque los judíos eran un pueblo que llegó a dispersarse ampliamente por el Mediterráneo, esto no llegó a afectar en modo alguno a su identidad, que estaba vinculada a su patria Judea y a su templo. Persiste el vínculo con una patria y con el templo, símbolo por excelencia de su religión (como el impuesto que pagaban cada año para el templo). Incluso las sinagogas de la diáspora constituían un medio por el que los judíos se relacionaban con el santuario central aunque residieran en ciudades distantes. Otra indicación de su relación con Judea eran las peregrinaciones o su aceptación de la ley. Los judíos era gente que había emigrado de su comunidad matriz, pero en quienes permanecía muy viva la memoria de sus orígenes y suscitaban y mantenían un específico y extremadamente potente sentido de identidad étnica. Todos poseían una identidad étnica, centrada en el templo de Judea, tanto si vivían allí como si no, o si tenían o no identidades étnicas derivadas de otros lugares de residencia (identidad anidada).

A nivel social, podemos afirmar que los extranjeros tienden a relacionarse entre ellos, lo que es normal dadas las diferencias culturales y lingüísticas, y al rechazo por parte de los autóctonos. La comunidad nacional ofrece al inmigrante información sobre cómo establecerse en la ciudad, sobre puestos de trabajo, vivienda, ofrece apoyo en su propia lengua y adaptado a sus necesidades. La red social de la sinagoga tuvo que desempeñar un papel fundamental en este ámbito. Varios autores han considerado a las sinagogas como si hubieran sido reconocidas como asociaciones voluntarias o collegia ${ }^{48}$, y per-

47 Los indicios que caracterizan a un grupo étnico son los siguientes rasgos comunes: 1) un nombre propio para identificar al grupo; 2) un mito de los antepasados comunes; 3) héroes, acontecimientos y sus respectivas conmemoraciones; 4) una cultura común que abarca asuntos como las costumbres, la lengua y la religión; 5) un vínculo con una patria, que o bien ocupan en ese momento o mediante la adhesión simbólica a una tierra ancestral, como hacen los pueblos que viven en la diáspora; 6) un sentido de solidaridad comunitaria, cf. PHILIP F. ESLER, Conflicto 72.

48 Cf. J. S. KLOPPENBORG - S.G. Wilson (eds.), Voluntary Associations in the GraecoRoman World, Routledge, London 1996; RICHARD S. Ascough, What Are They Saying About the Formation of Paulines Churches?, Paulist Press, New York/Mahwah, N.J. 1998, 7194; PH. A. Haland, Associations, Synagoges and Congregations. Claiming a Place in Ancient Mediterranean Society, Minneapolis 2003; STEPHEN SPENCE, The Parting 181-190. 
mitían suavizar la transición de una sociedad y cultura a otra. Tras los primeros momentos en que acomodarse es el objetivo más inmediato, a no ser que hubieran llegado a la ciudad como esclavos, la comunidad nacional prolonga su apoyo al inmigrante permitiéndole recuperar en su limitado tiempo libre su lengua materna, su gastronomía, sus celebraciones religiosas y cúlticas, la celebración de las fiestas como en familia y la amistad. El incremento de la presencia de inmigrantes de la misma nación, hace que éstos pierdan la posibilidad de integrarse y de relacionarse con los locales. Pero de las fuentes que se conservan, no se puede concluir que los judíos formaran un ghetto, más bien habría que excluir esa idea. El trato personal de la mayor parte de la población judía con los autóctonos sería mínimo, excluyendo claramente a la elite o a los ricos judíos que por diversos motivos entraban frecuentemente en contacto con los romanos. La mayoría de las relaciones se circunscribirían a las relaciones de ámbito laboral, con sus compañeros de trabajo, con quienes no mantenían relaciones fuera de la jornada laboral, o con quienes mantienen un trato cordial de trabajo o de vecindad, pero distante. Los judíos, orgullosos de su identidad y de sus costumbres, difícilmente aceptarían un matrimonio mixto entre gentil y judío, y evitarían todo contacto innecesario con familias no judías. Esto no quiere decir que estuvieran totalmente aislados de su ambiente. Otros grupos extranjeros e inmigrantes que llegaban a la Urbe acababan hacinándose en estos barrios pobres y populares, por lo que los judíos, extranjeros ellos también, se relacionaban y se movían fundamentalmente entre extranjeros ${ }^{49}$. Como es de suponer existiría un grupo judío que buscaba conscientemente una mayor relación e integración en la sociedad de acogida, quienes vendrían vistos con cierto recelo por sus compatriotas más religiosos.

\section{Relación de los judíos con los habitantes de Roma}

La relación e interacción de grupos extranjeros y autóctonos siempre crea y plantea la cuestión del grado de asimilación de los grupos que entran en contacto. La historia de la investigación de los judíos en la antigua Roma nos ha mostrado desde antiguo la imagen de que los judíos de la antigua

49 Este es un hecho que se constata incluso en las inmigraciones modernas. La interrelación de los extranjeros se circunscribe al inicio fundamentalmente a otros extranjeros, pues es más difícil entrar en contacto con los nativos de la sociedad de acogida por diversos motivos analizados por los sociólogos. Quien haya vivido en el extranjero de inmigrante habrá constatado y vivido esa experiencia. Se refuerzan los lazos con los connacionales en un primer momento, y se contacta con otros extranjeros por el trabajo realizado, por la zona donde se habita, por el idioma... 
Roma vivían en un aislamiento virtual para no perder su identidad judía, ya que no se tenían en consideración los materiales arqueológicos judíos en relación a materiales no judíos, o por una falta de método para llegar a tal conclusión ${ }^{50}$. Además, el uso frecuente del término "aislamiento" con su opuesto, "asimilación", dificulta ver la relación de los judíos y no-judíos en términos más complejos. La fascinación por una cultura no conlleva forzosamente la asimilación, sino que se pueden dar diversos grados. Tampoco se tiene que concebir la interacción entre judíos y no-judíos en términos estrictamente religiosos o en términos de ataque y contraataque o de conversión de no-judíos al judaísmo. L.V. Rutgers ${ }^{51}$ ha analizado el tema teniendo en cuenta los testimonios arqueológicos, las inscripciones y las fuentes literarias, comparando ese material judío romano con los hallazgos no-judíos. El estudio detallado de todos estos materiales le ha llevado a afirmar: "El uso de productos artísticos, del lenguaje o de formas literarias que son generalmente de la antigüedad tardía, va estrechamente relacionado con una tendencia a expresar la identidad que es, sin lugar a dudas, judía". La imagen que nos presenta este autor de la interrelación de los judíos romanos con su mundo circundante es la siguiente: "En lugar de vivir en un total aislamiento o ansiando asimilarse, los judíos romanos aparecen como activa y, sobre todo, conscientemente respondiendo a la evolución de la sociedad no-judía contemporánea. Interrelacionándose con no-judíos, los judíos romanos no renunciaron a su propia identidad. Es más, libremente tomaron prestados elementos de la cultura romana y adaptaron esos elementos a sus propias necesidades. De esta forma, afirmaron y mantuvieron su status como judíos". Judíos y no-judíos aparentemente estaban de acuerdo en que no era excluyente ser judío y participar en la sociedad romana. Aceptando que los judíos y no-judíos se relacionaron a diferentes niveles, sin embargo, es más complicado determinar la intensidad o incluso la naturaleza de los contactos entre los judíos y el resto de grupos existentes en Roma. ¿Hasta dónde llegaba la socialización?

50 Esta es la visión tradicional hasta los años 90, por ejemplo E. M. SMALLwood, The Jews under Roman Rule from Pompey to Diocletian, Brill, Leiden 1976, 123: los judíos se resistían a la asimilación, exceptuando en la cuestión superficial del lenguaje para el contacto cotidiano. L.H. FELDMAN, Jew and Gentile in the Ancient World. Attitudes and Interactions from Alexander to Justinian, Princeton University Press, Princeton 1993, 418.

${ }^{51}$ LeONARD Victor Rutgers, The Jews in Late Ancient Rome. Evidence of Cultural Interaction in the Roman Diaspora (Religions in the Graeco-Roman World 126), E.J. Brill, Leiden - New York - Köln 1995, 262.263. 


\subsection{Los judíos ante la sociedad y cultura romana}

La actitud de los judíos frente a la sociedad y cultura romana fue bastante compleja como mostrarán los estudios que vamos a exponer aquí. Los judíos se debatían entre conservar su identidad con todo lo que ello implicaba en el extranjero e integrarse en la sociedad de Roma. Presentamos primero las teorías más sencillas para pasar posteriormente a las que presuponen un complejo entramado de relaciones y diversos grados de integración.

John J. Collins dedica el capítulo séptimo de su libro a la interrelación entre judíos y gentiles. Muestra que las fuentes literarias analizadas en los capítulos precedentes ponen de manifiesto el deseo, por parte de los judíos de la diáspora, de apropiarse la cultura helenista, al mismo tiempo que mantenían su identidad judía. Es decir, buscaban reconciliar las dos facetas de su identidad que estaban en tensión en algunos puntos cruciales. La cultura helenista no era opcional para los autores de esos textos, incluso en ocasiones era problemática. Consecuentemente, esta literatura judía helenista presenta una actitud compleja y ambivalente hacia el mundo gentil y la cultura dominante. Existe una cierta polémica contra esa cultura, como era la cuestión de la idolatría, aunque la cultura como tal nunca fue rechazada. Sin embargo, gran parte de esta literatura judía manifiesta una gran preocupación por la aprobación gentil. La idea de una misión judía o de un proselitismo activo judío, sin embargo, que fue un dogma virtual de los estudios e investigaciones de principios del siglo $\mathrm{XX}$, ha sido cuestionada ampliamente en las últimas décadas 52 . John J. Collins llega a la siguiente conclusión: "los datos muestran más allá de toda duda razonable, que el judaísmo en la diáspora ganó adherentes que se pararon poco antes de la circuncisión... Se encuentra un amplio abanico de grados de relación o vinculación, no una clase con requisitos específicos o con un estatuto claramente definido en la sinagoga. La sátira XIV de Juvenal ilustra esta progresión: en primer lugar, el padre observa el sábado, después el hijo no adora otra cosa sino las nubes y la divinidad del cielo, y

52 S. MCKNIGHT, A Light among the Gentiles. Jewish Missionary Activity in the Second Temple Period, Fortress, Minneapolis 1991; S. J. CoHEN, Was Judaism in Antiquity a Missionary Religion?, en: M. MOR (ed.), Jewish Assimilation, Acculturation, and Accommodation. Past Traditions, Current Issues, and Future Prospects, University Press of America, Lanham, Md. 1992,14-23; M. Goodman, Mission and Conversion. Proselytizing in the Religious History of the Roman Empire, Clarendon, Oxford 1994. Los defensores más recientes de la misión judía son D. GEorgi, The Opponents of Paul in Second Corinthians, Fortress, Philadephia 1986, 83-151; L.H. FELDMAN, Was Judaism a Missionary Religion in Ancient Times?, en M. Mor (ed.), Jewish Assimilation 24-37; idem, Jews and Gentile in the Ancient World, Princeton University Press, Princeton 1993, 288-382. 
finalmente la circuncisión. No todos los denominados 'temerosos de Dios' eran necesariamente monoteístas o tuvieron que romper necesariamente sus lazos con la comunidad pagana. Existía también un espectro de opiniones de parte de los judíos, como podemos constatar de la historia de Izates" 53 .

Otro autor, Graydon F. Snyder ${ }^{54}$, estudia la interacción de los judíos con los no-judíos en Roma para la época que nos interesa. Distingue y define diversos conceptos y grados dentro de la interculturación e interacción cultural y religiosa: Asimilación/aculturación, enculturación, dominación cultural, inculturación e interacción cultural. Las fuentes literarias transmiten la idea de que los judíos de Roma no entraron en contacto con la cultura romana, pero este autor analiza la relación de los judíos con la cultura romana en base a las inscripciones, los símbolos y el lenguaje ${ }^{55}$. Además, considera que los primeros seguidores de Jesús en la capital del imperio fueron los agentes privilegiados de la inculturación judía. Graydon F. Snyder concluye que la inculturación ${ }^{56}$ judía de la cultura romana fue leve e insignificante. Mientras que los judíos utilizaron decoraciones comunes, sin embargo no aceptaron ningún símbolo importante del mundo romano ni contribuyeron con ninguno. En cuanto al lenguaje ${ }^{57}$, la situación es diferente, ya que adoptaron nombres romanos (aunque no el sistema onomástico romano) y contribuyeron con mu-

53 John J. Collins, Between Athens and Jerusalem. Jewish Identity in the Hellenistic Diaspora, second Edition, William B. Eerdmans - Dove Booksellers, Grand Rapids, Mi / Cambridge - Livonia, Michigan, 2000, 270.

54 GRAYDON F. SNYDER, The Interaction of Jews with Non-Jews in Rome, en: KARL P. DONFRIED - PETER RICHARDSON (ed.), Judaism and Christianity 69-90.

55 Sobre el estudio de inscripciones judías procedentes de Roma véase la obra clásica de H.J. LEON, Jews. Más reciente, con inclusión de nuevo material y distinta valoración de los artefactos cf. LEONARD VICTOR RUTGERS, The Jews 266: "The materials preserved in the Jewish catacombs of Rome suggest that the Jews buried there were neither assimilated nor isolated, bur rather people who interacted freely with non-Jews. At the same time they were people who interacted who had a strong sense of identity". D. NoY, Jewish Inscriptions of Western Europe. 2. The City of Rome, Cambridge 1995.

56 Este término describe un estilo de interacción cultural que "allows for an aggressive promotion of an outside myth without seeking to dominate or destroy an invaded culture" (p. 72).

57 J. GoOdnick Westenholz, The Jewish Presence 84s., constata que en las antiguas catacumbas judías de Monteverde y Vía Nomentana se conservan muchas más inscripciones en griego que en latín y en los siglos II y III los judíos fueron gradualmente absorbidos en la sociedad local desde el punto de vista linguístico (predominando el latín). Respecto a la elección de los nombres en la comunidad judía, hay que decir que predominan los nombres latinos frente a los griegos o semitas. Según L.V. RUTGERS, The Jews 209, "Far from being isolated linguistically, the Jews of ancient Rome adapted to their own purposes the two languages of the society in which they were living. Thus they succeeded in expressing an identit y that was unmistakably Jewish". 
chos nombres judíos a la cultura romana. Pero "los judíos de Roma construyeron una identidad propia frente a la cultura romana" 58.

En semejantes términos se expresa Margaret Williams al analizar la asimilación cultural de las comunidades judías en el imperio romano. Pocos judíos perderían la identidad judía, entre ellos menciona a Tiberio Julio Alejandro. "Infinitamente más numerosos eran los judíos de la diáspora que lograron, a pesar del alto grado de asimilación cultural, mantener un estilo de vida judío identificable"59. Para la mayor parte de los judíos, la observancia del sábado, la circuncisión y un monoteísmo sin imágenes divinas constituyeron el sine qua non de la conservación de la identidad judía60. El cumplimento de la Torá, además de otorgar a los judíos un sentido especial de identidad, los hacía aparecer como un elemento extraño dentro de la sociedad grecorromana.

Uno de los autores que más se ha interesado en estudiar el judaísmo en el mundo mediterráneo ha sido John M.G. Barclay61. Entre las indicaciones metodológicas que aplicará a su estudio, propone que hay conseguir algunos medios para distinguir entre los diferentes tipos o clases de helenización y los diferentes grados de compromiso social o cultural. Existían muchas facetas del helenismo y no todas ellas eran igualmente amenazadoras para la identidad judía. Este autor ha realizado una propuesta positiva distinguiendo entre asimilación, aculturación y acomodación, cada una de ellas medida en base a una escala apropiada. 'Asimilación' indica la integración social, teniendo en cuenta los contactos sociales, la interacción social y las prácticas sociales. La 'aculturación' se refiere a los aspectos lingüísticos, educacionales e ideológi-

58 GRAYDON F. SNYDER, "The Interaction" 90.

59 MARGARET Williams, Jews and Jewish communities in the Roman Empire, en: JANet Huskinson (ed.), Experiencing Rome. Culture, Identity and Power in the Roman Empire, Routledge, London 2000, 305-334, aquí 323.

60 MARgaret H. Williams, The Shaping of the Identity of the Jewish Community in Rome in Antiquity, en: Christians as a Religious Minority in a Multicultural City. Modes of Interaction and Identitiy Formation in Early Imperial Rome. Studies on the Basis of a Seminar at the Second Conference of the European Association for Biblical Studies (EABS) from July 8-12, 2001, in Rome, T \& T Clark International. A Continuum Imprint, London - New York 2004, 33-46. Idem, Being Jew in Rome. Sabbath Fasting as an Expression of RomanJewish Identity, en: JoHn M.G. BARCLAY (ed.), Negotiating Diaspora. Jewish Strategies in Roman Empire (Library of Second Temple Studies 45), T \& T Clark International. A Continuum Imprint, London - New York 2004, 8-18.

61 JoHN M.G. BARCLAY, Jews in the Mediterranean Diaspora. From Alexander to Trajan (323 BCE - $117 C E$ ), T \& T Clark, Edinburgh 1996. Véase la propuesta metodológica en el capítulo cuarto (pp. 82-102). Cf. también S.J.D. CoHEN, "Those Who Say They Are Jews and are Not": How Do You Know a Jew in Antiquity When You See One?, en: S.J.D. CoHEN - E.S. FreRICHS, Diasporas in Antiquity, Scholars Press, Atlanta 1993, 17-35. 
cos de una matriz cultural dada. La 'acomodación' alude al empleo o aplicación en que tiene lugar la aculturación, en concreto, el grado en que las tradiciones culturales judías y helenistas se fusionan o, alternativamente, se polarizan. La asimilación tiene que ver con la integración social y puede ser descrita como un cambio del universo simbólico personal en un contexto social.

Barclay aplica la teoría de integración social, con la distinción de tres clases y grados de helenización, fundamentalmente a los judíos de Egipto, pero dedica el capítulo décimo de su libro a los judíos de Roma. La contribución de los judíos romanos con el templo de Jerusalén (Cicerón, Flacco 28.67; Filón, Legatio 156) hizo que se conservara el sentido de pertenencia hacia el centro geográfico de sus tradiciones. Cualquiera que fuera la actitud de los individuos judíos hacia la asimilación, la comunidad judía estableció con éxito estructuras para la conservación de su distinción social. El autor considera que es difícil presentar un cuadro muy preciso sobre la interrelación de los judíos con su cultura circundante en la ciudad de Roma. No obstante, piensa que existen indicios suficientes para afirmar la existencia de diversos grados de asimilación: alto, medio y bajo. Las fuentes describen un número de casos de judíos que abandonaron el estilo de vida judío o, al menos, algunos aspectos cruciales con la finalidad de evitar ciertos dilemas sociales o con el objetivo promocionarse a nivel social ${ }^{62}$. Además, el derecho legal de la ciudadanía romana conllevaría una significativa asimilación social en diversos lugares del imperio. Otro grupo judío logró mantener una asimilación de grado medio. Se trata de un amplio grupo que incluye a judíos con significativos lazos sociales con el mundo no judío, quienes, sin embargo, preservaron su identidad judía. Este grupo se podría subdividir a su vez en varias subcategorías. Aquí encontraríamos a los judíos con ciudadanía romana, a los judíos prominentes en la vida pública ciudadana o la asimilación de artistas judíos de Roma. Los modelos de vida que se observan en la diáspora mediterránea sugieren que los judíos no estaban ni aislados a nivel cultural y social, ni simplemente mezclados en una amalgama social. Aunque los límites pudieron ser definidos y establecidos en diferentes circunstancias, fue precisamente la habilidad de mantener estas fronteras mientras continuaba el contacto social diario con los no judíos lo que constituyó el mayor logro de las comunidades de la diáspora ${ }^{63}$. Un tercer amplio grupo experimentaría una asimilación mínima, en parte gra-

62 Idem 323: Josefo, Ant 18,141; abandonaban las costumbres judías para evitar la vergüenza o el desastre (Tácito, Ann 2,85.4), para evitar pagar el impuesto del fiscus Iudaicus (Suetonio, Domitiano 12,2); Marcial, Epigramas 7,82;11,94: "Such cases indicate the pressures to conform faced by socially successful Jews" (324).

63 Idem 329. 
cias a los distritos residenciales judíos dentro de la ciudad. Los barrios judíos, por ejemplo el Trastévere, no evitaban el contacto con otros grupos, pero al menos posibilitaba, a quien lo deseara, el poder minimizar los contactos sociales con los "extraños". En otros casos, es difícil precisar el grado de asimilación.

El fuerte entramado de prácticas (la separación de las comidas, la circuncisión, la observancia del sábado, el rechazo del culto pluralista e icónico extranjero), la comunidad y la coherencia interna hicieron del judaísmo una tradición extraordinariamente perdurable, no por su aislamiento total del contexto circundante, sino por la claridad de diferenciación en puntos socialmente decisivos ${ }^{64}$.

John M.G. Barclay65 distingue entre "raza" (características genéticas y biológicas cuyas manifestaciones son frecuentemente inmutables) y etnia, que es la combinación de parentesco y costumbre, reflejando tanto la genealogía compartida como el comportamiento común. Por tanto, la identidad judía en la diáspora no era una mera cuestión de linaje ni una simple cuestión de práctica cultural, sino que se basaba en la combinación de estos dos factores interrelacionados. La etnicidad (la combinación de linaje y costumbres) fue el núcleo o la esencia de la identidad judía en la diáspora. Esto se puede ver en cinco aspectos: la terminología étnica típicamente empleada por los judíos de la diáspora ${ }^{66}$ para describirse a sí mismos; la visión que los no judíos tenían de los judíos como un grupo étnico; la perfecta resocialización de los prosélitos que se unieron a la comunidad judía ${ }^{67}$; el reconocimiento de la importancia de la endogamia (matrimonios dentro del grupo étnico), y la educación de los niños en el estilo de vida judío.

Recientes estudios han aparecido en este campo utilizando nuevas perspectivas. Así Magnus Zetterholm aplica una visión científico-social a los procesos de asimilación e interrelación de los judíos de Antioquía. Aunque se

${ }^{64}$ Idem 444.

65 John M.G. Barclay, Jews 402ss. Philip E. EsLer, Conflicto 82ss diferencia entre etnicidad y raza: "El problema de las teorías raciales es que pretenden que las divisiones entre los pueblos, que son construcciones sociales..., tienen una base biológica". (83). La raza serían tipos ideales socialmente construidos mediante los que se categoriza a los pueblos.

66 Sobre la diáspora judía: GeRRIE TER HAAR (ed.), Strangers and sojourners. Religious communities in the diaspora, Peeters, Leuven 1998; IsAIAH M. GAFNI, Land, center and diaspora. Jewish constructs in late antiquity (Journal for the Study of the Pseudepigrapha. Supplement Series 21), Sheffield Academic Press, Sheffield 1997; GideON BoHAK, Ethnic continuity in the Jewish diaspora in antiquity, en: JOHN RAYMOND BARTLETT (ed.), Jews in the Hellenistic and Roman Cities, Routledge, London 2002, 129-148.

${ }^{67}$ MorTon SMITH, The Gentiles in Judaism 125 BCE - CE 66, en: William Horbury - W.D. DAVIES - JOHN STURDY, The Cambridge History of Judaism. Vol III:The Early Roman Period, Cambridge University Press, Cambridge 20012 , 192-249. 
centra en una ciudad distinta a la nuestra, su metodología puede ser interesante para nosotros. Este autor, basándose en un estudio del proceso de asimilación realizado por M.M. Gordon, propone las siguientes variables de asimilación $68:$ a) aculturación: la familiaridad con la cultura matriz de la sociedad receptora, incluyendo su lenguaje y educación. b) asimilación estructural: la relación primaria con los miembros de la sociedad receptora y el ingreso en pandillas, clubes e instituciones de la sociedad anfitriona a nivel de grupo primario. c) asimilación marital: esposarse fuera del propio grupo. d) asimilación identificacional: el desarrollo del sentido de identidad basado exclusivamente en la sociedad anfitriona. e) asimilación con actitud receptora: se caracteriza por la ausencia de prejuicios. f) asimilación cívica: es la ausencia de poder o conflictos de valores. A ello hay que añadir las nociones de modelos culturales intrínsecos (emana de la herencia) y extrínsecos (no hace referencia a una herencia étnica específica).

Zetterholm hace uso de una teoría del cambio religioso derivada de los estudios de migraciones internacionales en el contexto europeo occidental moderno. Ya que los cambios de religión siempre encierran un aspecto social, usará además una teoría de la asimilación para explicar la relación entre la comunidad judía y la sociedad circundante. Dado que el judaísmo de la diáspora tuvo que adaptarse considerablemente a la sociedad helenista, nos llevará a ver la relación del helenismo y el judaísmo en general. Concluye que en Antioquía se pueden diferenciar cuatro grupos judíos diferentes ${ }^{69}$. En primer lugar, un grupo judío al margen del judaísmo. Se trataría de un grupo fuertemente asimilado y con tendencia a separarse del judaísmo. Este grupo representa la culminación del proceso de asimilación a la sociedad anfitriona. En segundo lugar, se encontraría el grupo contrario a la asimilación. Éste estaría formado por los religiosos tradicionalistas con un fuerte compromiso con la observancia de la Torá y, posiblemente, vivirían aislados, tanto de otros judíos como de la sociedad gentil. Asimismo, aparecen testimonios de dos manifestaciones innovadoras del judaísmo: de un lado, los seguidores del movimiento mesiánico de Jesús y, de otro lado, un grupo de judíos muy helenizados que, sin embargo, sí se consideraban judíos. Además, tenemos que contar con una colectividad de judíos antioquenos que no encontrarían cabida en ninguno de los grupos anteriormente mencionados. Probablemente se pudiera extrapolar esa estructuración del judaísmo antioqueno a la capital del imperio.

${ }^{68}$ Magnus ZetTerholm, The Formation of Christianity in Antioch. A Social-Scientific Approach to the Separation Between Judaism and Christianity, Routledge, London - New York 2003, 68ss.

69 Idem $90-92$. 
Este mismo estudioso intenta ver la existencia de diversos grupos judíos en la capital del imperio. Con este objetivo, se fija en los nombres de las sinagogas romanas, algunas de ellas se remontarían al siglo I d.C. El denominador común para los nombres de las sinagogas es que reunían a personas que tenían algo en común ${ }^{70}$. Sus miembros podían proceder del mismo lugar o tenían un origen social común, y se puede asumir que compartían una ideología. Algunas sinagogas llevaban su nombre para honrar a personas de importancia para la comunidad judía (Augusto, Agripa, Volumnias, Herodes). Existió una "sinagoga de los hebreos", que bien pudo ser la primera comunidad de judíos en Roma. Otra era denominada "sinagoga de los vernaclesianos", compuesta de personas nacidas esclavas en casa de sus amos, o se referiría a un grupo de judíos helenistas, quienes en oposición a los hebreos, habían adoptado costumbres romanas, o pudiera incluso aludir a los judíos romanos nativos en contraposición a los inmigrantes ${ }^{71}$. Si esta interpretación es correcta, sus miembros pudieran haber pertenecido a los judíos helenizados en Roma en contraposición a los miembros de la sinagoga de los hebreos. Los judíos que observaban la ley de forma tradicional, utilizando sus conocimientos de la sociedad helenista para rechazarla, no podrían pertenecer a la misma sinagoga en la que sus miembros admiraban el helenismo y acogían a los gentiles dentro de sus reuniones ${ }^{72}$.

Tras exponer las diversas teorías sobre el grado de interrelación de los judíos con su sociedad circundante en Roma, podríamos adoptar la idea expresada por Stephen Spence ${ }^{73}$, para quien las catacumbas judías de Roma

70 Esto suele ser verdad cuando se funda la sinagoga o se le otorga el nombre, pero también hemos de contar con la posibilidad de cambios dentro de la composición u orientación de sus miembros con el tiempo, dependiendo fundamentalmente de los líderes que estén al cargo de dichas sinagogas. Las comunidades no son estructuras estáticas ni inmutables.

71 K. Hedner-ZetTerholm, The Jewish Communities of Ancient Rome, en: B. OlsSON - D. MITTERNACHT - O. BRANDT, The Synagogue of Ancient Rome. Interdisciplinary Studies, Paul Aström, Stockholm 2001, 131-140.

72 La diversidad de las sinagogas romanas ha sido demostrada por M.H. WILLIAM, "Structure" 129-141; STUART S. MilLER, The Rabbis and the non-existent monolitic synagogue, en: Steven Fine (ed.), Jews, Christians and Polytheists in Ancient Synagogue. Cultural Interaction during the Greco-Roman Period, Routledge, London - New York 1999, 71-86. Véase el epígrafe "Synagogagemeinden als Vereine oder autonome politische Gebilde - das Beispiel Rom" en STEFAN Krauter, Bürgerrecht und Kultteilnahme. Politische und kultische Rechte und Pflichten in griechischen Poleis, Rom und antikem Judentum, Walter de Gruyter, Berlin - New York 2004, 370-379. CARSTEN ClAUSSEN, Meeting, community, synagogue - different frameworks of ancient Jewish congregations in the diaspora, en: BIRGER OLSSON - MAGNUS ZETTERHOLM (ed.), The ancient synagogue from its origins until 200 C.E. Papers presented at an international conference at Lund University, october 14-17, 2001 (Coniectanea biblica. New Testament series 39), Almqvist \& Wiksell, Stockholm 2003, 144-167.

73 STEPHEN SPEnCE, The Parting 25. 
muestran a una gente que no estaba asimilada ni aislada, sino a un grupo que se relacionaba libremente con no-judíos. Al mismo tiempo, era un grupo que poseía un fuerte sentido de identidad. Si bien es verdad que pudieron existir diferentes comunidades judías en Roma, pero los elementos que han perdurado no nos permiten reconstruir el tipo de personas que pertenecían a cada comunidad en particular, o cómo se relacionaban las comunidades entre ellas. Los materiales de las catacumbas tampoco permiten dividir a los judíos romanos en grupos más romanizados y grupos más tradicionales.

Gracias a los rasgos comunes de identidad étnica judía compartidos por sus miembros, especialmente por su relación a Judea y al templo de Jerusalén, la mayor parte de los judíos romanos se pudieron definir a sí mismos como miembros de un grupo en particulares categorías socialmente compartidas. De esta forma fortalecieron el sentido de identidad compartida con los miembros del endogrupo intensificando, al mismo tiempo, el sentido de contraste entre ellos mismos y los miembros de los exogrupos. Esa era la situación de la mayor parte de los judíos en Roma.

No obstante, la noción de identidad del grupo no es inflexible, sino que emergerían divisiones. Con la configuración de una sociedad multicultural y multiétnica romana, se dio una forma de integración "débil" del inmigrante judío quien, gracias al aumento de la tolerancia de la población autóctona, pudo mantener la identidad cultural de origen dentro de su nueva sociedad. Existirían ocasiones en las que algunos miembros del grupo judío consideraron que ciertos rasgos de la identidad compartida no coincidían con sus intereses o sus posiciones, y si esta posición se considera fundamentalmente incompatible con la identidad endogrupal, entonces no es extraño que algunos miembros se distanciaran de su grupo e intentaran asimilarse en la sociedad anfitriona. Se puede constatar una cierta ambigüedad en la autoexpresión cultural de los judíos en la diáspora. No se asimilaron totalmente a la cultura mayoritaria ni eran totalmente distintos de ella. Por consiguiente, debemos afirmar cierta diversidad en los grados de asimilación.

\subsection{La actitud de los romanos y otros pueblos hacia los judíos de Roma.}

La idea que nos ofrecen estas visiones de interacción cultural entre los judíos romanos con su entorno social creo que pueden ser válidas. No obstante, son simplistas. Todas ellas tienen en cuenta únicamente un polo de la interacción, el judaísmo, considerado éste como un grupo multiforme y heterogéneo. Pero se olvidan de analizar el otro polo de la interacción, la sociedad romana. Suelen presentar esta última como un ente homogéneo y abstracto. 
Pero la sociedad romana era mucho más compleja, heterogénea y divergente que el judaísmo. Nos encontramos con una sociedad romana multicultural y multiétnica.

Los miembros de un grupo étnico tienden a estereotipar a otros grupos étnicos, es decir, a considerar que todos sus miembros comparten las mismas características (a menudo catalogadas de forma negativa). Frente a las virtudes cardinales griegas, los griegos tenían la estrategia común de estereotipar a los extranjeros proyectando sobre ellos lo contrario de los valores de la población autóctona. Esta práctica se basa en un sentido subyacente de superioridad étnica y en el mantenimiento de sus límites. Los romanos eran ciertamente etnocéntricos; tenían aversión a otros pueblos, incluyendo a los judíos. Pensaban que los judíos eran antisociales y, por tanto, misántropos, sobre todo por su oposición a participar en las solemnidades imperiales. Esler aplica la formulación de la etnicidad basada en Barth a los grupos del antiguo Mediterráneo. Las diferentes culturas estaban orientadas fuertemente hacia el grupo.

Los judíos eran conocidos por sus costumbres religiosas distintivas y por su solidaridad social. Tres características en particular llamaban la atención a los romanos: el rechazo a comer carne de cerdo, el encendido de las lámparas del sábado y el descanso sabático. Los judíos eran frecuentemente acusados de odiar al género humano. Tal acusación no dice nada sobre la visión judía de los no judíos, sino que hace referencia a la costumbre general judía de interrelacionarse entre ellos mismos. Mejor informados estamos sobre el concepto que tenía la elite cultural romana sobre el judaísmo. Sin embargo, debemos leer sus comentarios en su contexto original si realmente queremos comprender la situación que están describiendo. Estos escritores eran xenófobos o reacios a la influencia que pudieran ejercer los extranjeros sobre sus connacionales. También algunos emperadores, entre los que destacan Calígula y Trajano, expresaron públicamente su sentimiento adverso respecto al ethnos judío, ya que deseaban eliminar a este pueblo 'nacido en esclavitud'74. Del mismo modo, las afirmaciones de Josefo han de ser leídas con cautela, pues tiende a realizar una apología del judaísmo ${ }^{75}$. En Roma, se puede afirmar que la reacción más popular ante judaísmo fue la indiferencia.

\footnotetext{
74 Calígula: Josefo, AJ 18,275; Trajano: Arr, Parth. F79 = Stern (1980) n 332a, y Appiano, Bciv. II 90 (380) = Stern (1980) n 350 .

75 Especialmente Josefo, Contra Ap 2,282-283, donde muestra que una gran masa estaba deseosa de adoptar las observancias religiosas judías: "Muchos pueblos y desde hace mucho tiempo, han demostrado gran interés por nuestras prácticas piadosas, y no hay una sola ciudad griega, ni un solo pueblo bárbaro donde no se haya extendido nuestra costumbre del descanso semanal y donde los ayunos, el encendido de las lámparas y muchas de
} 
Los vecinos de los judíos en los barrios y sus compañeros de trabajo no eran generalmente "romanos genuinos o autóctonos", sino en el mayor de los casos se trataba de otros extranjeros. Por tanto, los judíos entran en contacto normalmente con otros pueblos o grupos, que como ellos, son inmigrantes en la gran metrópoli. El lenguaje griego les facilita la comunicación con los provenientes del este ${ }^{76}$. El número muy reducido de inscripciones judías encontradas en latín (para esta época), hace pensar que la mayor parte de la población judía se relacionaba con gente de lengua griega, y por tanto con otros extranjeros. Generalmente, se ha aplicado erróneamente a esos "otros" que no eran judíos el término de "gentiles", pero Roma no estaba compuesta de judíos y gentiles. El concepto de "gentil" no puede ser usado como un término descriptivo para un grupo social o étnico. Se trata más bien de una descripción religiosa realizada desde el punto de vista de los judíos. Ni tampoco los gentiles pueden ser considerados como una clase singular y concreta de gente, con una respuesta única al judaísmo y hacia los judíos.

La mayor parte de los vecinos de los judíos eran peregrinos procedentes del oriente, quienes poseían ya sus creencias y prácticas religiosas bien establecidas. No conocemos casi nada de cómo respondió esta gente ante el judaísmo, ya que los pobres no suelen dejar constancia histórica directa de sus sentimientos 77 . Sin embargo, no es cierto que abandonaran su identidad étnica o la religión de sus antepasados en la Roma cosmopolita. Como para los judíos, la conservación de sus creencias y prácticas religiosas era un componente importante para preservar su identidad étnica. Por eso hay que suponer que los persas, los sirios o los egipcios mantuvieron grandes comunidades separadas, centradas en sus propios cultos 78 .

Los miembros de estos grupos encontraban su identidad mediante la diferenciación de otros exogrupos, lo que típicamente se expresaba en la este-

nuestras leyes respecto a la comida no sean observadas. Se esfuerzan también en imitar nuestra concordia y nuestra generosidad, nuestro amor al trabajo en los oficios y nuestra firmeza en defensa de las leyes ante la tortura".

76 BRUNO ROCHETTE, La langue comme facteur d'intégration ou d'exclusion. L'Athènes de Périclès et la Rome de Cicéron, en: MARIA GABriella ANGELi BerTinelli - ANGELA DonATI (eds.), Serta Antiqua et Mediaevalia. VII. Il Cittadino, lo Straniero, il Barbaro fra integrazione ed emarginazione nell'Antichità. Atti del I Incontro Internazionale di Storia Antica (Genova 22-24 maggio 2003) (Università degli Studi di Genova, Dipartimento di Scienze dell'Antichità e del Medioevo. Storia Antica), Giorgio Bretschneider Editore, Roma 2005, 3-20.

77 StePhen Spence, The Parting 45, n. 110, cree que no se puede aplicar la relación amor-odio entre los judíos y sus vecinos romanos. Dado el largo periodo en que las varias comunidades vivieron pacíficamente en la misma región de Roma, se puede describir que las masas romanas eran más bien indiferentes hacia los judíos.

78 Cf. G. La Piana, "Foreign Groups". 
reotipación de los miembros del exogrupo, pero también, en ocasiones, mediante el conflicto. No obstante, llama la atención la ausencia de conflictos entre judíos y otros pueblos extranjeros en Roma (en contraposición a Alejandría o Antioquía). Este hecho se puede explicar desde una perspectiva de la identidad social, mediante algunos enfoques para reducir el conflicto entre grupos. Pero la forma más sencilla de explicar esa paz entre distintos grupos étnicos en Roma es que las autoridades romanas no permitirían bajo ningún concepto que se alterara el orden ni se permitiera la existencia de altercados entre extranjeros. La expulsión de los causantes de disturbios es frecuente en Roma, por lo que las minorías estaban muy interesadas por su propio bien en no verse involucradas en conflictos, cuyas consecuencias pudieran ser nefastas. Roma no consentiría altercados en el corazón del imperio. Entre la masa indiferente, existieron sin lugar a dudas personas abiertamente hostiles y otros eran simpatizantes de los judíos y de su religión ${ }^{79}$.

Eso no quiere decir que los sentimientos entre los grupos fueran de total concordia y amistad. La relaciones de los judíos con estos grupos, y especialmente con los griegos, estarían marcadas por la hostilidad, no por los eventos acaecidos en Roma, sino en otros lugares del imperio. Christopher Stanley ${ }^{80}$ ha trazado las grandes líneas del conflicto entre los judíos y los griegos ${ }^{81}$ desde mediados del siglo I a.C. hasta el 117 d.C. Sorprende la frecuencia y la amplitud que tenían lugar estos conflictos. El conjunto de estos episodios puede considerarse como el resultado de dos grupos étnicos que maniobran por conseguir el poder y el status dentro de la estructura de un gobierno nuevo. Para nuestro período destacan los conflictos de Alejandría (38-41 d.C.), en Antioquía y en Filadelfia en Palestina. Teniendo presentes dichos conflictos, es muy verosímil que los grupos procedentes de esos pueblos mostraran cierto recelo y aversión ante los judíos. A eso hay que añadir la competencia que existiría por conseguir los escasos puestos de trabajo, así como el deseo por parte de las minorías de adquirir espacio de influencia en las autoridades y familias influyentes romanas. Tener un buen padrino, siempre ayuda.

79 STEPHEn SPEnCE, The Parting $47 \mathrm{~s}$.

80 Christopher D. STANLEY, "Neither Jew Not Greek": Ethnic Conflict in GraecoRoman Society, en: JSNT 64 (1996) 101-124.

81 Phillp E. EsLer, Conflicto 113ss, considera que los conflictos de los judíos en la diáspora fueron exclusivamente con los griegos, es decir que poseían esta identidad étnica, caracterizada por la utilización de la lengua griega y las implicaciones de otros rasgos de su cultura, tanto si teníari o no otra identidad étnica. Pero creo que Esler no tiene razón al asignar bajo la categoría de "griegos" a todos los enemigos de los judíos, pues sin lugar a dudas según las categorías usadas por este mismo autor, estos judíos también serían griegos, en cuanto que esa sería su identidad étnica derivada del lugar de residencia (identidad anidada). 
La contienda por el poder típico de las comunidades de la diáspora, bien sea en rivalidad con otras "diásporas" o en contienda con la comunidad anfitriona viene analizada en un artículo sobre Josefo. Barclay escribe sobre la imagen de Egipto en Contra Apionem demostrando que Josefo se hace eco del prejuicio romano contra los egipcios en un intento por alinear su obra con la visión de la comunidad anfitriona y para refutar la tendencia romana de vincular los cultos judíos y egipcios como importaciones extranjeras. La ratificación del prejuicio romano contra otra comunidad extranjera es el camino para auto-habilitar a su propia gente 82 .

Una de las razones de la complejidad de analizar el fenómeno de la interacción es que se trata de un proceso dinámico que no siempre se adecua a nuestras categorías analíticas. No resulta fácil construir un modelo que dé cuenta en toda su riqueza del comportamiento de los inmigrantes judíos en Roma. Además, la falta de datos dificulta la tarea. A pesar de la heterogeneidad propuesta por algunos autores, se pueden dibujar dos grandes tendencias. La primera es la presencia de readaptaciones y reconfiguraciones que afectan más a la periferia del sistema cultural-identitario, y no tanto a su núcleo duro. La plasticidad de esas adaptaciones externas es suficiente para no causar efectos disonantes. La segunda tendencia es la evolución progresiva de los acontecimientos: el factor tiempo. De manera que, frente a una fase migratoria de provisionalidad (caracterizada muchas veces por búsqueda de recursos económicos para la supervivencia), el establecimiento y, en muchos casos, la formación o reagrupamiento en una familia, suelen ir acompañados de un mayor esfuerzo por la reconstrucción de la identidad; es decir, que las preocupaciones culturales sustituyen progresivamente a las preocupaciones legales o económicas.

\section{La oferta religiosa judía}

En toda interrelación mutua se aprende y se ofrece algo a los demás. Las relaciones entre judíos y no judíos se dieron a muchos niveles, especialmente en el ámbito social, económico-laboral, cultural... ¿Qué era lo que más llamaba la atención a quien entraba en contacto con los judíos en Roma? Sin lugar a dudas, su religión, por eso nos centraremos aquí brevemente en un aspecto de las múltiples relaciones posibles: la dimensión religiosa.

82 Cf. J.M.G. BARClay (ed.), Negotiating Diaspora. Jewish Strategies in the Roman Empire (Library of Second Temple Studies), T \& T Clark International Continuum, London 2004, veáse el artículo del editor. 
La religión tradicional romana era inadecuada para muchos habitantes de Roma, que buscaban algo más. Muchos participaron en los cultos mistéricos orientales (Mitras, Isis...). A otros les atraía el monoteísmo y el carácter moral del judaísmo. Algunas prácticas o rituales judíos parece que llamaron la atención de los no judíos. Los autores romanos presentan un cuadro complejo, revelando una cierta ambivalencia entre "desagrado y temor, criticismo y respeto, atracción y repulsa"83. En la ciudad de Roma, algunos no judíos adoptaron diferentes costumbres judías. Contra esta influencia judía en la vida romana reaccionó Séneca ${ }^{84}$. Se puede pensar que el carácter social de la sinagoga debió llamar la atención a otros extranjeros no judíos. El papel de la sinagoga como centro de la comunidad donde tenía lugar un gran número de actividades caritativas, subrayaban los aspectos de la vida que otros emigrantes carecían. La ética (cuidado de los enfermos, no abortos, mayor natalidad...) y el sistema de relaciones sociales generado gracias a la sinagoga eran atractivos para los inmigrantes y los autóctonos. El monoteísmo ejercía cierta atracción, aunque creo que siempre se ha exagerado este aspecto. Feldman indica tres aspectos atractivos: la antigüedad del judaísmo, las virtudes cardinales y Moisés como líder ideal. Desde la perspectiva de un forastero extranjero, carente de contactos sociales iniciales, parecería una decisión muy racional asociarse con la comunidad judía, dado que ella aportaba una red social de decisiva importancia. Aunque más lógico es que un inmigrante buscara apoyo inicial entre sus connacionales.

\subsection{El judaísmo ¿religión proselitista?85}

Es el momento de tratar aquí sumariamente si el judaísmo fue una religión misionera ${ }^{86}$ en el siglo I. Nadie puede negar la evidencia de que algunos gentiles se convirtieron al judaísmo en esa época. Sin embargo, divergen las

83 P. SCHÄFER, Judeophobia. Attitudes toward the Jews in the Ancient World, Harvard University Press, Cambridge, MA 1997, 210. Cf. Z. YAVETZ, Judeophobia in Classical Antiquity, en: Journal of Jewish Studies 44 (1993) 1-22; Idem, Judenfeindschaft in der Antike, C.H. Beck, München 1997.

84 Según S. Agustín, Civ 6,11, Séneca afirma que "las costumbres de esta raza han adquirido tal influencia que ahora son recibidos en todo el mundo. Los vencidos ahora dan leyes a sus vencedores".

85 Cf. supra nota 52. Shaye J.D. CoHEN, Did Ancient Jews Missionize?, en: BiblR 19 (2003) 40-47. J. ZANGENBERG, Mission in der Antike und im antiken Judentum, en: Zeitschrift für Neues Testament 8/15 (2005) 12-21.

86 J.C. PAGET, Jewish Proselytism at the time of Christian Origins: Chimera or Reality?, en: JNST 62 (1996) 65-103, para una visión de las discusiones. Este autor defiende una 
opiniones referentes a la magnitud de las conversiones ${ }^{87}$ y a las razones por las que tuvieron lugar. Se trataría del grupo de los prosélitos ${ }^{88}$. No obstante, la existencia de los prosélitos no prueba que el judaísmo desarrollara una actividad proselitista.

Dos textos han sido la clave para inferir y afirmar la actividad proselitista del judaísmo: Mt 23,15 y Horacio, Sátiras I 4,139-14389. “!Ay de vosotros, escribas y fariseos hipócritas, que recorréis mar y tierra para hacer un prosélito, y cuando llega a serlo, le hacéis hijo de condenación el doble que vosotros!" (Mt 23,15). El contexto de Mt es una serie de maldiciones contra los escribas y fariseos, por tanto un grupo particular de judíos palestinos, lo que no se puede extrapolar ni utilizar como testimonio de la práctica del judaísmo de la diáspora. No parece ser histórica la indicación de recorrer mar y tierra, sino que serían exageraciones retóricas. Además, los estudios sobre los fariseos antes de la destrucción del templo no les asignan normalmente actividades fuera de Palestina, ni estaban preocupados por la cuestión de los gentiles, sino por la práctica religiosa de sus connacionales judíos. Por su parte, el símil empleado por Horacio forma parte de un tratamiento humorístico. Debemos concluir que no sólo existen pocas menciones del proselitismo judío, sino que también son mínimos los indicios que sugieran que los judíos se encargaron de la instrucción de los convertidos o emprendieran la conversión de simpatizantes mediante recursos literarios. Sin lugar a dudas, que existieron gentiles que frecuentaban las sinagogas y eran instruidos en la ley de Moisés, pero era una instrucción fundamentalmente pensada para judíos.

Por tanto, no existirían testimonios convincentes para postular que el judaísmo de la diáspora emprendió un programa proselitista. Esto no significa que no estuvieran interesados en la salvación de los gentiles y esperaban que se convirtieran al final de la historia por una actuación divina. Mientras tanto, el judaísmo tenía la función de ser luz entre las naciones. Según Stephen

solución intermedia entre el maximalismo de Georgi y Feldman y los minimalistas. Según Paget (p. 102), no se puede afirmar que cada judío fuera un misionero potencial ni que las sinagogas fueran centros misioneros organizados para expandir su religión ni con la intención de convertir a los gentiles, pero probablemente existió una conciencia misionera entre algunos judíos.

87 STEPHEN SPEnCE, The Parting 48, cree que no existen testimonios para apoyar la idea de que el proselitismo judío tuviera un gran éxito durante el siglo I.

88 Dio Casio, Historia Romana 117,14,1-3; Josefo, Ant 18,81-84; 20,20.17-96; Hechos 6,6; así como algunas inscripciones de catacumbas romanas JIWE II 62,218, 224, 392?, 489, $491,577$.

89 "Vendrá en auxilio mío la turbamulta de poetas, más numerosa de lo que imaginas, y como sectarios judíos te obligaremos, quieras que no, a alistarte en nuestras filas". 
Spence ${ }^{90}$, todo parecería indicar un lento proceso de asimilación más que un proselitismo activo.

Más interesante es si existió un grupo de gentiles con un claro interés en el judaísmo, que pudiera haber adoptado algunas costumbres judías y participado en actividades de la sinagoga sin haberse convertido al judaísmo. Los encuentros en las sinagogas no eran privados, sino abiertos a todos los interesados. Filón y Josefo estaban orgullosos de la apertura de la comunidad judía a los forasteros ${ }^{91}$. Aunque la terminología no es unívoca ni clara ${ }^{92}, \operatorname{los}$ judíos de la antigüedad denominaban a esos gentiles o a algunos de ellos, tanto en griego como en hebreo (theosebes, temerosos de los cielos, en latín, metuentes), "temerosos de Dios", un uso confirmado por Josefo, Hechos, la literatura rabínica y diversas inscripciones ${ }^{93}$. Especial atención merecen las inscripciones encontradas en Afrodisias y en Panticapaion. En la primera inscripción aparece el concepto de theosebes entendido éste como un gentil no prosélito, quien de alguna manera está formalmente vinculado a la comunidad judía. Sin embargo, algunos estudiosos cuestionan la existencia de este grupo ya que los términos theosebes y metuentes se referirían a los judíos observantes y, por tanto, significaría simplemente "pío" o "religioso".

A.T. Kraabel ${ }^{94}$ y R.S. MacLennan han puesto en tela de juicio la existencia de un grupo de "temerosos de Dios" que estuviera vinculado a las sinagogas de la diáspora. Sus principales argumentos son los siguientes. Kraabel examina los lugares de seis sinagogas de la diáspora (Dura Europas, Sardis, Priene, Delos, Stobi y Ostia), y no encuentra ninguna prueba en estas ciudades de la adhesión gentil al judaísmo. No existen inscripciones que indiquen la existencia de este grupo, y la que se encontró en la sinagoga de Afrodisias (siglo III d.C.) es problemática, ya que es muy tardía y utiliza el término theosebes (lín. 34), en lugar de phoboumenos o sebomenos, términos usados

90 STEPHEN SPENCE, The Parting 51s.

91 Filón, Legat 211; Josefo, Bell 7,45.

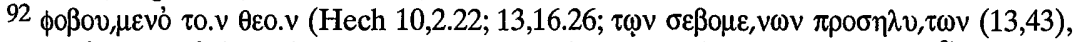

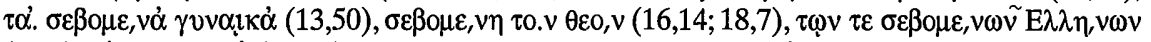

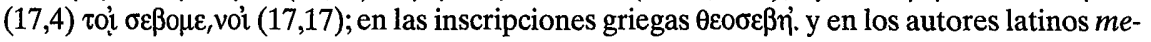
tuentes.

93 Cf. LAURENCE H. KANT, Jewish Inscriptions in Greek and Latin, en: ANRW II 20 (1987) 671-709, aquí 686-690, para quien las inscripciones sugieren que "there was not a sharp distinction between Jews and God-fearers and that God-fearers were often members of Jewish synagogues" (690). Para una colección amplia de material sobre estos términos cf. F. Siegert, Gottesfürchtige und Sympathisanten, en: JSJ 4 (1973) 109-164.

94 A.TH. KraAbel, Inmigrants, Exiles, Expatriates and Missionaries, en: L. Bormann (ed.), Religious Propaganda and Missionary Competition in the New Testament World. Essays Honoring D. Georgi (NT.S 74), Leiden 1994, 71-88. 
en Hechos. El concepto tiene un papel teológico específico en la narrativa de Lucas, quien más o menos lo habría inventado para mostrar cómo el cristianismo legítimamente se convirtió en una religión gentil. Las referencias en la literatura grecorromana son pocas y no apoyan la presentación que ofrece Hechos. Además, el mismo hecho puede ser interpretado de formas diversas. D. Flusser entiende con este concepto el rotundo éxito del judaísmo, mientras que Hengel considera que la presencia de un gran número de temerosos de Dios muestra el completo fracaso del judaísmo, que pudo ser corregido únicamente en el cristianismo. Concluyen MacLennan y Kraabel afirmando que el título de theosebes de la inscripción de Afrodisias es simplemente una alabanza sobre el carácter moral de los benefactores no judíos. Por tanto, no se debería asumir que theosebes tuviera un sentido técnico o semitécnico en la antigüedad. De hecho, el término puede indicar simplemente que los gentiles eran amables con sus conciudadanos judíos ${ }^{95}$.

En términos semejantes se expresa Stephen Spence respecto a la inscripción de Afrodisias: "La inscripción de Afrodisias es un testimonio de la diversidad del término theosebeis. Puede referirse a quienes pertenecen a un grupo vinculado (probablemente a nivel religioso) a la sinagoga, o puede indicar a ciertos benefactores que no tienen ninguna vinculación religiosa con la sinagoga. Sin embargo, en ninguno de los casos establece que los temerosos de Dios fueran considerados como un grupo oficial dentro de la sinagoga. En ambas caras de la inscripción, 'temeroso de Dios' debe ser entendido como un título honorífico concedido a determinadas personas gentiles y no como un grupo formal dentro de la sinagoga al que los gentiles se podían unir"96. La motivación de cada temeroso de Dios en particular puede ser muy diferente, bien sea religiosa o social, pero no los podemos considerar como "semi-prosélitos". Estas personas decidieron no convertirse al judaísmo ni se apartaron de sus propias comunidades étnicas, por lo que continuaban participando en los cultos paganos. Más bien, quisieron incluir en sus propias prácticas religiosas algunos aspectos de la piedad judía. Sólo los prosélitos se convirtieron al judaísmo, y únicamente los convertidos pertenecían a la sinagoga. No existía una conversión a medias ni la pertenencia parcial a la sinagoga. Algunos temerosos de Dios se convertirían al judaísmo, otros permanecerían paganos. En cualquier caso, la sinagoga estaba abierta para ellos. Pero mientras eran gentiles, no formaban parte de la sinagoga. Podían estar vinculados, pero no pertenecían a la sinagoga.

95 Robert S. MacLennan - A.T. KraAbel, The God-Fearers. A Literary and Theological Invention, en: BARev 12 (1986) 46-53, aquí 51.

96 STEPHEN SPENCE, The Parting 57. 
La tesis de Kraabel ${ }^{97}$ y MacLennan no es totalmente convincente. De la ausencia de testimonios epigráficos referentes a un grupo de gentiles interesados en el judaísmo no se puede inferir la inexistencia de tal grupo. Como indica J.A. Overman, este argumento es exclusivamente ex silencio, y si no nos

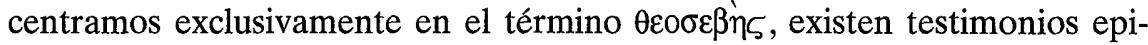
gráficos y papirológicos del fenómeno, como bien ha indicado Feldman. La inscripción de Afrodisias (s. III d.C) es un buen ejemplo de la existencia de un grupo de gentiles estrechamente relacionados con la sinagoga y denominados theosebes $^{98}$. Aunque se pueden cuestionar algunas de las pruebas de Feldman ${ }^{99}$ referidas a los gentiles temerosos de Dios, la aportación de datos en favor de la existencia de gentiles interesados en la sinagoga es impresionante. Parece correcta la afirmación de Overman, de que a la luz de las evidencias "there is every reason to assume the presence of a class of Gentiles associated with the synagogue is an authentic reflection of the diverse composition of diaspora Judaism in the late first century"100. Otros autores consideran que Kraabel ha exagerado negando la existencia de gentiles simpatizantes de los judíos en el siglo I. La atracción de los cultos orientales en todo el imperio habría suscitado que personas inquietas estuvieran interesadas en conocer un poco más de cerca el judaísmo. Sin embargo, la presentación lucana en $\mathrm{He}$ chos $(6,5)$ tampoco debe ser aceptada sin más. El problema en muchos estudios no es tanto la existencia de gentiles simpatizantes del judaísmo, sino la magnitud de este grupo. Los pocos testimonios existentes hacen pensar que el grupo no fuera muy númeroso ${ }^{101}$.

97 A.T. KRAABEL, The Disappearance of the 'God-Fearers', en: J.A. OVERMAN - R.S. MaCLEnNan (ed.), Diaspora Jews and Judaism. Essays in Honor of, and in Dialogue with A. Thomas Kraabel, Scholars Press, Atlanta 1992, 119-130.

98 J. Reynolds - R. TANnEnbaum, Jews and Godfearers at Aphrodisias. Greek Inscriptions with Commentary, Cambridge, Cambridge Philological Society 1987, 56-57; FELDMAN, Jew 362-9.

99 L.H. Feldman, Jew and Gentile in the Ancient World. Attitudes and Interactions from Alexander to Justinian, Princeton University Press, Princeton, NJ, 1996, 244-358; The Omnipresence of the God-Fearers, en: BAR 12,5 (1986) 58-63.

100 J.A. OVERMAN, The God-Fearers: Some Neglected Features, en: JSNT 32 (1988) 17-26, aquí 24. S.J.D. CoHEN, The Beginnings of Jewishness. Boundaries, Varieties, Uncertainties, University of California Press, Berkeley CA 1999, 62, afirma con relación al término God-fearers, que "the debate about the precise meaning and aplication of this term ought not to obscure the fact that such gentiles existed". Véase también I. LEVINSKAYA, The Book of Acts in its First Century Setting. Vol. 5: The Book of Acts in its Diaspora Setting, Eerdmans, Grand Rapids, MI 1996, 51-103, para una discusión extensa del problema referida al presupuesto de la existencia de temeros de Dios.

101 Richard S. Ascough, What Are They Saying About the Formations of Pauline Churches?, Paulist Press, New York/Mahwah, N.J. 1998, 19s. 
Shaye J.D. Cohen ha analizado la complejidad de las actitudes de los gentiles hacia el judaísmo de forma admirable. Distingue diversas formas para un gentil de expresar su respeto o afecto por el judaísmo102. Los gentiles podrían admirar algún aspecto concreto del judaísmo. Podían admirar el poder del Dios de Israel incorporándolo a su panteón. Esta era una forma normal para cualquier persona dentro del sistema religioso grecorromano de relacionarse con una divinidad extranjera. Podían financiar a los judíos o mostrarse amigos suyos. Existen gentiles benefactores de la comunidad judía y ésta les confería títulos honoríficos. El hecho de que los gentiles ayudaran a comunidades judías, no necesariamente implica que tuvieran un afecto especial por el judaísmo ${ }^{103}$. Sin embargo, desde una perspectiva social, hay que considerarlos más cercanos a la comunidad judía que los gentiles que sólo reconocían el poder de Dios de Israel, porque mantenían una relación cordial con la comunidad judía ${ }^{104}$. Cohen distingue cinco grados o categorías de gentiles, para él denominados "veneradores de Dios" (=God-fearers), relacionados con el judaísmo y su religión: gentiles que sentían admiración por algunos aspectos del judaísmo (categoría 1), o quienes reconociendo el poder del Dios de los judíos actuaban como 'normales' politeístas (categoría 2) y difícilmente llamarían la atención. Existían gentiles que eran visiblemente amigos de los judíos (categoría 3), que practicaban los rituales de los judíos (categoría 4) o que veneraban al Dios de los judíos, negando o ignorando el resto de los dioses (categoría 5). Estos gentiles mostraban una relación con el judaísmo poco común en Roma, de tal forma que en algunas ocasiones eran llamados "judíos" por otros gentiles, o incluso ellos mismos se habrían considerado de alguna forma judíos. Pero los judíos, ¿también los habrían llamado judíos? Según Cohen, no estamos seguros, pero lo más probable es que no, ya que los temerosos de Dios eran más paganos que judíos ${ }^{105}$.

Finalmente, los no judíos se podían convertir al judaísmo, lo que incluiría tres elementos: la práctica de las leyes judías, la devoción exclusiva al Dios

102 S.J.D. COHEN, Crossing the Boundary and Becoming a Jew, en: HTR 82 (1989) 1333 , identifica siete niveles de vinculación al judaísmo: 1) admirando algún aspecto del judaísmo, 2) incorporando el Dios judío a su panteón pagano, 3) ayudando a los judíos, 4) practicando algún ritual judío, 5) venerando el Dios de los judíos e ignorando los dioses paganos, 6) uniéndose a la comunidad judía, y 7) la conversión al judaísmo.

103 Sobre los benefactores de la comunidad judía, cf. TESSA RAJAK, Benefactors in the Greco-Jewish diaspora, en: HUBERT CANCIK - HERMANN LiCHTENBERGER - PETER SCHÄFER, Geschichte - Tradition - Reflexion. Festschrift für Martin Hengel zum 70. Geburtstag. Bd. 1: Judentum, Mohr, Tübingen 1996, 305-319.

104 S.J.D. COHEN, The Beginnings 140-174, 147.

105 Idem, 171. 
de Israel y su integración en la comunidad judía. Pero hay algunos indicadores que insinúan que el status de un convertido era en cierto modo ambiguo.

Esta misma cuestión se plantea Stefan Krauter ${ }^{106}$. ¿Los temerosos de Dios pudieran ser vistos y considerados como miembros de la comunidad sinagogal? Según este autor, no se puede dar una respuesta general y válida para todos. La inscripción de Afrodisias (siglo III d.C.) nombra un amplio número de qeosebh.j, entre ellos algunos miembros de un grupo que estudian y rezan en común la torá. La inscripción CIRB 71 (Panticapaion, del siglo I d.C.) deja entrever con su formulación, que los temerosos de Dios eran aceptados como parte de la comunidad judía. A estas evidencias epigráficas hay que añadir los testimonios literarios. Según Hechos 13,16.26, si el discurso tuvo lugar en una sinagoga, hay que contar con la presencia asidua de no judíos, y a quienes se dirige como un grupo estable y concreto. En Josefo (Bell 7,45 ) se dice que los judíos consideraban a los griegos que frecuentaban sus servicios religiosos como una parte de sí. Esto indica que no era la regla general, pero que al menos no era imposible que los no judíos, que participaban regularmente en la vida de la comunidad sinagogal, fueran considerados como miembros de las sinagogas.

Se puede decir que la posición del judaísmo antiguo no fue unánime frente al reclutamiento de prosélitos. Algunos judíos no esperaban de forma pasiva ante los interesados, sino que estaban preparados y decididos a enseñar a los no judíos cuestiones de su religión. Sin embargo, no se puede probar la existencia de un celo misional judío o una misión sistemática judía con gran producción de literatura misional. Concluye este estudioso, que una parte del judaísmo antiguo pensaba que la única forma legítima de venerar al Dios de Israel, era llevar una vida religiosa conforme al judaísmo. Esto significaba que los no judíos debían optar ante la disyuntiva de convertirse plenamente al judaísmo o no. Por el contrario, otra parte del judaísmo antiguo, tal vez más numerosa, era más abierta frente a todo tipo de adoración del Dios de Israel realizada por los no judíos. Esto significa que ofrecieron a los no judíos múltiples posibilidades de participar en la religión judía: aceptación de algunas costumbres judías, participación regular en la sinagoga, la conversión...

La existencia de los temerosos de Dios no es un desdichado compromiso entre las tendencias misioneras del antiguo judaísmo y su anclaje nacionalétnico. Los temerosos, en su diversidad, fueron aceptados como temerosos por muchos judíos, aunque no por todos. La actitud positiva tenía una moti-

106 STEFAN KRAUTER, Bürgerrecht und Kultteilnahme. Politische und kultische Rechte un Pflichten in griechischen Poleis, Rom und antikem Judemtum (BZNW 127), Walter de Gruyter, Berlin - New York 2004, 218. 
vación no exclusivamente política y social, es decir, que buscaran reforzar su posición ante posibles conflictos. Esta motivación jugó su papel, pero además se pensó que los temerosos podían realmente adorar al Dios judío. Por tanto, su existencia va en contra de la afirmación de que el judaísmo antiguo no tenía una orientación misionera hacia el exterior, sino que era una unidad indisoluble de religión y etnia, una alianza solo entre Dios y su pueblo. "Das antike Judentum war vielmehr nicht exklusiv, sondern offen für die Partizipation"107.

Recientemente Johannes Woyke 108 analiza asimismo el concepto de "los temerosos de Dios o adoradores de las imágenes de los dioses" centrándose en los escritos de Filón de Alejandría. De sus escritos se cristalizan tres grupos con afinidades con el judaísmo de la diáspora. En primer lugar, se encuentran los prosélitos, quienes mediante la circuncisión se han convertido total y formalmente al judaísmo; en segundo lugar, están los prosélitos de ideología que reconocen un Dios y lo adoran de forma exclusiva. En tercer lugar, habría que situar a los simpatizantes, quienes no sólo rehuyen la adhesión social al judaísmo, sino también la adoración de un Dios en el marco ideológico de un politeísmo monárquico o un monoteísmo sincretista. En la práctica es difícil diferenciar estos tres grados. ¿De dónde provenían la mayor parte de los prosélitos de la diáspora helenística judía? De los destinatarios de los escritos Filón y Josefo se puede concluir que provenían de círculos instruidos y educados. Posiblemente se pudiera tratar de benefactores del judaísmo de la diáspora, influyentes a nivel financiero y social.

Respecto al número de gentiles interesados en la participación de los servicios religiosos judíos, sólo se puede especular, pero más bien eran pocos. Stephen ${ }^{109}$ afirma que no existen pruebas que confirmen la participación de los gentiles en el servicio religioso judío, ni existen testimonios que sugieran la existencia de un gran número de gentiles que frecuentaban la sinagoga.

Pero si existía una clase de gentiles que estaban aparentemente interesados tanto en aspectos religiosos del judaísmo como en el trato social en las comunidades judías, ¿por qué no se convirtieron al judaísmo? Diversas razones frenaban a los temerosos de Dios a dar el paso definitivo de la conversión formal y total: a) la idea de la adoración exclusiva de un dios era algo extraño para la reflexión religiosa grecorromana. Les era más sencillo incorporar

107 Idem 227. Ampliamente en B. WANDER, Gottesfürchtige und Sympathisanten. Studien zum heidnischen Umfeld von Diasporasynagogen (WUNT 104), Mohr Siebeck, Tübingen 1998.

108 JOHANNES WOYKe, Götter, 'Götzen', Götterbilder. Aspekte einer paulinischen 'Theologie der Religionen' (BZNW 132), Walter de Gruyter, Berlin - New York 2005, 152s.139.

${ }^{109}$ STEPHEN SPENCE, The Parting 54. 
el Dios de Israel a su panteón y continuar adorando otros dioses. La conversión al judaísmo conllevaba problemas a nivel teológico y social. Podía afectar a la carrera política y social, ya que gran parte de la vida pública y cívica incluía la participación en las actividades cúlticas públicas. Además, convertirse en prosélito suponía no ser aceptado por la comunidad judía como realmente judío, sino odiado dos veces por la comunidad gentil: tanto por ser un renegado a nivel político y religioso como por ser judío. Para algunos gentiles, tener la posición del temeroso de Dios podía ser una alternativa más atractiva, ya que podía disfrutar de lo mejor de los dos mundos: mantenía la identidad religiosa y social gentil y, al mismo tiempo, contaba con ser aceptado por la salvación del Dios de Israel.

Frecuentemente se ha afirmado que existía en el mundo romano la obligación de participar en ciertos actos cúlticos de carácter público. Los nacidos judíos habrían sido excluidos de tales actos gracias a sus privilegios, los prosélitos por el contrario no. La cesación en estas obligaciones religiosas podría conllevar sanciones muy severas. Pero estas afirmaciones no son correctas. No existía una obligación de participar en estos actos, aunque siempre era considerado un acto de lealtad. La conversión al judaísmo tampoco era un acto punible durante los reinados de Claudio y Nerón ${ }^{110}$. Sin embargo, un temeroso de Dios podía evitar determinadas situaciones sociales desagradables de forma más sencilla que un prosélito. Quien evitaba de forma estricta el culto de los dioses y se mantenía fiel a los mandamientos de la pureza y de la alimentación, en sí no era punible, pero podía provocar incomprensión, rechazo y oposición 111 . Otra dificultad para la conversión al judaísmo pudiera provenir de la identificación entre la "etnia" (ethnos) y la religión judía, lo que podría conllevar al convertido el reproche de una dudosa lealtad política frente a su polis o gente. En este sentido, nos parecen un poco excesivas las afirmaciones de Zetterholm: "Es mucho más probable que las comunidades judías no exigieran de los gentiles, temerosos de Dios, renegar de su compromiso con el culto oficial, ya que las acusaciones de haber conducido por mal cami-

110 Véase la actitud de los primeros emperadores hacia el culto al emperador, cf. $D$. ÁlvAREz CINEIRA, Religionspolitik 55-97: "Einerseits beanspruchten Kaiser solche göttlichen Ehren nicht (Caligula und Domitian [Sueton, Dom. 13] waren jedoch Ausnahmen). Anderseits ist nachgewiesen, daß alle Kaiser den Kaiserkult mehr oder weniger (inoffiziell) akzeptierten. Der Kult um den Kaiser speilte jedoch bei der Frage der Verfolgungen keine oder nur eine bescheidene Rolle" (97). Cf. también STEFAN KRAUTER, Bürgerrecht 224: "Eine Pflicht zum Kult gab es - wie in Kapitel 5 gezeigt werden wird - nicht. Der Übertritt zum Judentum war, was den Zeitraum, den diese Arbeit untersucht, angeht, nicht strafbar".

111 Esto es lo que muestra las expresiones negativas de Tácito, Hist. 5,5,2 y Juvenal, Sátiras $14,100.103$ s., aunque como pertenecientes a la clase senatorial no son representativos de todos los no judíos de la antigüedad. 
no a los gentiles, fácilmente podían afectar a los privilegios judíos. Los collegia existieron bajo la condición de que no violaran la ley pública"112.

Los judíos no podían exigir algo a quien no formaba parte integrante de sus comunidades. Difícilmente puede un extranjero exigir mucho cuando se encuentra en tierra extranjera, por eso era mejor mantener buenas relaciones con sus simpatizantes que presentar actitudes impositivas. Sería una tolerancia lógica en la diáspora, actitud que presumiblemente hubiera sido muy distinta en Palestina, donde la mayor presión social judía hubiera situado al temeroso ante la disyuntiva de una opción.

En Roma existiría un amplio espectro de relaciones entre judíos y no judíos durante el primer siglo d.C. Aunque era posible traspasar las fronteras entre la religión judía y el resto de las religiones -un judío podría convertirse en gentil y viceversa-, es evidente que el proceso era complicado. Debido a cierta repulsa, tanto por parte de la comunidad judía como de la gentil para aceptar la transmigración cultural y religiosa, las sinagogas helenistas se convirtieron en lugares importantes para la interacción cultural.

Presumiblemente, los convertidos al judaísmo no debieron ser muy numerosos. La mayor parte de gentiles que tenían relaciones con el judaísmo eran simpatizantes, "temerosos de Dios", que dependiendo de su grado de relación con el judaísmo, adoptaron algunas prácticas judías, como la observancia del sábado, ciertas leyes alimenticias y las características más importantes del código moral o incluso el monoteísmo judío. Estas conversiones se debieron fundamentalmente a los lazos de interrelaciones sociales existentes entre judíos y no judíos, a la atractividad de ciertas prácticas religiosas del judaísmo o incluso a la actividad receptiva más que proselitista de algunos miembros del judaísmo113. Aunque no se puede excluir que existieran simpatizantes entre las clases acomodadas romanas ${ }^{114}$, pero la mayor parte serían extranjeros que se asentaban en los barrios pobres y que diariamente entraban en interrelación mutua con los judíos, bien fuera por motivos laborales, económicos o de otra índole. Por tanto, se trata de peregrini o residentes extranjeros.

Es en el ámbito de los simpatizantes y prosélitos judíos donde los seguidores cristianos intentan ganar sus primeros adeptos ${ }^{115} \mathrm{y}$ donde, posiblemen-

112 Magnus ZetTERHolm, The Formation 128s.

113 J. GOODNICK WESTENHOLZ, The Jewish Presence 82 concluye de la expulsión de los judíos de Roma en tiempos de Tiberio (19 d.C.) a causa de la actividad proselitista de los judíos: "The implication of the decree of 19 C.E. is that Jewish practices were widespread among all social strata in Rome, from freedmen to the upper classes".

114 Josefo, $A J$ XX 195; Vita 16 menciona las buenas relaciones de los judíos con la corte imperial (Popea y Alituros).

115 Cf. JUSTIN TAYLOR, Where Did Christianity Come From?, Liturgical Press, Collegeville, Minnesota 2001, 93-100. 
te a causa de su predicación respecto a Cristo y por su proselitismo entre los temerosos de Dios, entrarían en conflicto con el resto de los miembros sinagogales. Se trataba de un asunto interno judío. Pero la confrontación desembocó en altercados dentro de una o varias sinagogas, alterando la paz de Roma, de tal forma que en el año 49 d.C. el mismo emperador Claudio tuvo que intervenir mediante un decreto de expulsión de los alborotadores ${ }^{116}$. Entre estos se encontraban seguidores judíos de Jesús y judíos que se oponían al contenido de esas predicaciones. Pablo dirige su carta a los Romanos teniendo presente la composición de estas comunidades y las relaciones existentes entre judíos y no judíos.

\section{Conclusiónt}

Como la mayor parte de los emigrantes pobres que por distintos motivos se han visto forzados a abandonar su país, los judíos de Roma se dedicarían en primer lugar a las cuestiones prácticas de la vida cotidiana, especialmente a la supervivencia117. Ante ellos se presentaba la cuestión de la participación en los negocios y en el trabajo sin comprometer sus marcas esenciales de identidad como judíos. ¿Cómo competir en esta joven, pero muy competitiva sociedad sin provocar conflictos peligrosos con otros grupos? ¿Cómo equilibrar o sopesar la asimilación necesaria para sobrevivir y prosperar en la nueva sociedad anfitriona junto con el mantenimiento de las antiguas tradiciones de su tierra de origen, que situaba fronteras y preservaba la identidad?

Los judíos de Roma no eran los únicos que tenían que afrontar estos retos. En diversos grados, cada grupo inmigrante tenía que encontrar un término medio entre identidad y asimilación. En esta época, Roma crecía con la llegada de nuevos inmigrantes provenientes de todas las partes del imperio. Estos inmigrantes desarrollaron estrategias similares para mantener de alguna forma la identidad separada en un ambiente cosmopolita. La organización en asociaciones voluntarias de emigrantes de cada país, así como la ubicación de su hábitat en áreas contiguas o cercanas fueron estrategias decisivas para preservar su cultura. Un punto central en esta identidad era mantener el culto de los dioses del país de origen.

116 Cf. Helga Botermann, Das Judenedikt des Kaisers Claudius. Römischer Staat und Christiani im 1. Jahrhundert (Hermes 71), Franz Steiner Verlag, Stuttgart 1996; D. Álvarez Cineira, Religionspolitik

117 Wayne A. MeEks, Corinthian Christians as Artificial Aliens, en: Troels EngbergPedersen (ed.), Paul Beyond the Judaism / Hellenism Divide 129-138. 
Cada comunidad étnica en una ciudad griega o romana, tenían diversas marcas distintivas, pero los judíos, sin lugar a dudas, eran mucho más conscientes de sus límites étnicos que el resto de los pueblo inmigrantes. La tendencia del pueblo judío a mantenerse apartado constituía una de las características frecuentemente mencionadas por los autores paganos sobre los judíos. Incluso, el mimo Filón reconoce que Israel no está separado físicamente de otras naciones, pero se diferencia por sus costumbres distintivas y características (Mos.1.278). En nuestra carta a los romanos encontramos signos judíos para trazar y delimitar la identidad, como son la abstinencia de la carne y del vino (Rom 14s) o la celebración de las fiestas judías.

Los inmigrantes judíos, para preservar su identidad, siguieron el modelo que otros grupos inmigrantes habían desarrollado en los periodos helenista y romano, formando asociaciones centradas en el culto de su dios nativo y observando algunas de sus costumbres ancestrales, que preservaban sus vínculos con el lugar de origen y establecían límites en torno a esa comunidad transplantada. No obstante, esas barreras podían ser flexibles y, como hemos mostrado, existían diversas formas y grados de entrar en interacción con el resto de los grupos inmigrantes de la ciudad de Roma. Por consiguiente, no se puede hablar de una única forma de asimilación. La mayor parte de los judíos intentaron conjugar el vivir en una ciudad cosmopolita, siendo extranjero, junto con la conservación de su identidad étnica y de sus tradiciones religiosas fundamentales. Un papel especial jugaron las sinagogas a la hora de integrar a los nuevos inmigrantes judíos dentro de la comunidad judía romana, y aunque éstas no eran homogéneas, ayudaron sin embargo a estrechar las relaciones internas entre sus miembros y con su país de origen, especialmente con el templo. Además servían de centro de enseñanza de sus tradiciones para las segundas y terceras generaciones.

Este tipo de organización interna no indica que los judíos formaran un gueto, ni vivieran totalmente aislados. Es más, reinterpretaron sus requerimientos bíblicos sobre la incorporación de extranjeros (gerim) en la vida cúltica de Israel para aplicarlos a su nueva situación, ahora que ellos mismos eran extranjeros. Las relaciones con otros grupos extranjeros no siempre serían fáciles, pero no conocemos conflictos destacables en la capital del imperio con otros grupos. Experimentarían el recelo de algunos extranjeros y romanos, mientras que otras personas que entraron en contacto con los judíos se convertirían en amigos e incluso en benefactores. Fruto de estos contactos positivos, y sin excluir una actitud aperturista y de acogida de algunos judíos hacia los extranjeros, sería la existencia de un pequeño grupo de prosélitos, quienes abandonaron sus creencias anteriores y se pasaron a la comunidad judea. Otros extranjeros no dieron el paso de la conversión, pero mantuvie- 
ron relaciones cordiales con las sinagogas y aceptaron algunas de las prescripciones judías. Entre ellos existirían diversos grados de vinculación con el judaísmo.

Los seguidores de Jesús que llegaron a Roma llevarían su actividad proselitista entre los vinculados de alguna forma al judaísmo. La mayor apertura hacia los gentiles y la no exigencia de la circuncisión hicieron que el número de seguidores de Jesús no procedentes del judaísmo creciera rápidamente. El edicto de expulsión del emperador Claudio hizo que esta tendencia se intensificara y que pronto los pagano-cristianos se convirtieran en mayoría dentro de las comunidades cristianas. Estos acontecimientos políticos influyeron considerablemente para que ahora la secta de esos que estaban iniciados en el Mesías Jesús se separasen de la asociación de inmigrantes judíos, convirtiéndose en un culto distintivo y no identificado con una identidad étnica única. Cuando Pablo escribe la carta a los Romanos, la mayoría del nuevo culto ya no son judíos, sino gentiles. Esta asociación multiétnica, sin embargo, parece y actúa en algunas ocasiones como una étnica, es decir, una asociación inmigrante -y especialmente como la asociación judea en la forma que recibe a los prosélitos. El bautismo es un ritual de disasimilación, si es que se puede usar este término, creando fronteras donde anteriormente no existían, indicando o señalando la unión de gentes de diversos orígenes en un único cuerpo, una asociación semejante a una étnica de extranjeros artificiales. Otro ritual distintivo sería la Cena del Señor. No obstante, a pesar de la existencia de estrategias para crear lazos endogrupales dentro del cristianismo, pronto surgieron conflictos internos cristianos como consecuencia de la amalgama de identidades étnicas dentro de la misma comunidad (Rom 14-15). Mediante su carta, el apóstol intentará mantener unidos a dos subgrupos del movimiento de Jesús que se encontraban en un estado de tensión.

Esto nos muestra que si ya las primitivas comunidades cristianas estaban abiertas al encuentro de diversas culturas e identidades dentro del mismo grupo, nos invitan a abrir nuestras comunidades locales al fenómeno de la inmigración dentro del mundo globalizado, pues es una forma de enriquecer la vida cristiana y a los mismos cristianos, aunque no exenta problemas y dificultades. Habrá que idear estrategias intragrupales para superar los conflictos de identidad y de intolerancia. Pues no hay nada menos objetivo que un ser humano guiado por sus prejuicios.

David Álvarez Cineira Estudio Teológico Agustiniano Valladolid 